Chapter II

HUMANITY 

Soloviev would never again return to the sort of metaphysical speculation that had characterized the works of his early period. The process of the hypostatization of the absolute we find in Philosophical Principles, for example, while leaving a definite trace on the philosopher's evolution, finds only a distant echo in his later years. Whatever the merits of his early work, however, it should be recalled that the theoretical pursuit of 'first things' had never been conceived by Soloviev as a goal in itself but as a certain kind of mise-en-scène or preparatory act, a 'clearing of the intellectual ground for the foundations of a spiritual building of the future.' There is a pull toward the human that inheres in the nature of Soloviev's metaphysics, and which lends it a certain mobility somewhat at odds with an understanding of the field as the science of what is ultimate, or changeless. As he writes to his cousin at age eighteen, 'only human nature and life are worth studying in themselves. ${ }^{1}$ Already very early on in his career, the anthropological element is primary, with metaphysics prominent only insofar as it is related to human life.

The dynamism in Soloviev's conception of God derives from this inability to think the divine without the human, a coupling rendered conceptually by the philosopher's term theanthropy. In his lectures on the subject, Lectures on Theanthropy (1877-81), God, who for Soloviev was so emphatically 'not of the dead, but of the living,'2 becomes the protagonist in the 'universal drama's of world history that was to lead humanity to liberation from death and salvation. So sweeping is the historical scope of this work, so thoroughgoing its association of

Solov'ev, "Nepodvizhno," p. 156.

Mark 12.27; Matthew 22.32.

$\mathrm{S}^{2}$, II, p. 55. 
the divine with the movement of humanity in time, that hereafter it becomes impossible to talk of Soloviev's conception of God without reference to her relationship to historical humanity, and to her saving acts in history whose culmination the philosopher saw in the Incarnation and Resurrection of Christ. 'It is not cosmocentrism nor anthropocentrism,' writes Vasilii Zen'kovskii, 'that define Soloviev's approach to all questions but historiocentrism. This is not to say that he transforms every problem into a historical survey of its various resolutions but that, for him, all "faces" of being reveal themselves in history, in the development of humanity."

That history occupies an important place in Soloviev's philosophy is not surprising, given that he was the son of one of Russia's most eminent historians. And yet, faced with the elevated claims he makes for humanity and its role in the realization of the Kingdom of God, as well as the frequent characterizations of Soloviev's thought as a variation on the theme of Gnostic anthropocentrism, ${ }^{5}$ the locus, not of the human at the very centre of his philosophical schema, but of history is worth stressing. The human being, Soloviev asserts against Protagorus, is not the measure of all things. Although he claims that humanity is the potential 'form' for absolute content, Soloviev understands this potentiality not merely as innate to the human spirit, i.e. existing in an interior space and requiring merely the right attitude to become reality. Rather, this potential is itself historicized, and its gradual realization becomes not only a matter for human spiritual aspiration but a grandly conceived historical project which involves, in a way that may at times appear contradictory, not only humanity but the rest of the natural world. History becomes the arena in which authentic being is disclosed, and the place of meeting between humanity and the divine.

There is therefore a dynamism in Soloviev's understanding of what it means to be human, which allows him to move beyond the static view of Gnosticism or any number of philosophies before or contemporary

$4 \quad$ V.V.Zen'kovskii, 'Russkie mysliteli i Evropa,' pp. 114-140 (p. 24).

5 For two recent examples of this approach, see I. I. Evlampiev, Istoriia russkoi metafiziki $v$ XIX-XX vekakh. Russkaia filosofiia v poiskakh absoliuta, 2 vols, St Petersburg, 2000, I, pp. 183-86; A. P. Kozyrev, Solov'ev i gnostiki. 
with him. ${ }^{6}$ The essence of humanity is here not fixed but entirely open in terms of its future. The human subject in Soloviev, unlike its Aristotelian counterpart which had enjoyed such decisive influence in the development of Western metaphysics, cannot be thought of apart from its context. Humanity is pre-eminently an historical being, and its being is defined and conditioned by this, its rootedness in time.

This understanding of humanity as ontologically embedded in history allows Soloviev to develop a projectional view of human nature with a strong orientation toward the future. Humanity is perpetually involved in the movement of becoming, with the conditions of its present forever ceding to the prerogatives of the future. His anthropology is thus geared toward determining the direction of humanity's movement in history and sketching the contours of a future, ideal humanity at the 'end' of time. From here stems the overwhelming emphasis throughout his thought on the task of humanity, the activity required of him if the goal of the historical process is to be fulfilled. It is tempting, therefore, to do as Tomáš Masaryk does and associate the 'second absolute' which we arrived at in the last chapter ('All-Unity in a state of becoming') directly with humanity. ${ }^{7}$ But such a conclusion fails to understand the essence of Soloviev's theanthropy: what is becoming, in the historical sense, is not a something - be that humanity or any other natural phenomenon - but a relationship: namely, the interaction between the divine and human principles. For the same reason, it is impossible to speak of creation itself - the material world as a whole - as the subject of becoming in his thought. Yet in an inscrutable way, which Soloviev attempts to articulate in his thought on the body of Christ, All-Unity does indeed become in humanity (though not exclusively for it), in the process of which the material world too is drawn into its movement.

6 Sergei Khoruzhii regards the inclusion of process and 'anthropological dynamics' into Soloviev's conception of human being as one of his principal contributions to world philosophy. Even in Hegel and Schelling, he argues, 'the dynamic elements in their picture of reality, spirit and reason, had to large extent become autonomized by isolating themselves from the human and removing themselves from anthropology.' S. Khoruzhii, 'Solov'ev i Nitsshe v krizise evropeiskogo cheloveka,' in Opyty iz russkoi dukhovnoi traditsii, Moscow, 2005, pp. 249-286 (p. 260).

7 T.G. Masaryk, Spirit of Russia: Studies in History, Literature and Philosophy, 3 vols, London, 1955, II, p. 247. 


\section{ANTHROPOGENY AND HISTORY}

Soloviev was amongst the first generation of thinkers to mature in the wake of the scientific, philosophical and religious implications of Charles Darwin's publication of Origin of the Species in 1859, which appeared in Russian translation five years later. The philosopher seems to have been aware of evolutionary theory from an early age and, especially in his later work, reveals not only a close understanding of Darwin's ideas but even a close affinity with them. ${ }^{8}$ As with other scientific work he drew on, he sought not to undermine Darwinian evolutionary theory from the combative perspective of religionism but to incorporate it within a broader theoretical framework that did justice to his particular understanding of historical development as it pertained to both humanity and the natural world. That evolution was not only compatible with the biblical account of the creation of humanity, but that it was only the combination of the two that could offer a holistic picture of reality is a conviction which, in one form or another, pervades much of his thinking on the nature of history. In his influential work of 1895, Justification of the Good, he wrote:

The order of the substantial is not the same as the order of the phenomenon. Higher, more positive and fuller forms and conditions of being exist (metaphysically) before those lower than they, although they appear or are disclosed after them. This does not negate evolution which, as fact, is impossible to negate [...] The conditions of the phenomenon derive from natural evolution, but that which is disclosed from God. ${ }^{9}$

The pre-existence of certain phenomena in history, Soloviev argued, does not mitigate against later evolutionary developments laying claim to a 'fuller form of being.' Applying this to the great challenge that Darwinian theory represented for the biblical belief of Soloviev's era - the postulation that the human species evolved from the primate

8 Sergii Bulgakov writes that Soloviev was a 'passionate advocate of scientific evolutionism,' the difference between the philosopher and outright Darwinists being that, for the former, 'natural science offered [... ] an answer not to scientific problems but to those of Naturphilosophie.' Bulgakov, 'Chto daet sovremennomu soznaniiu filosofiia Vl. Solov'eva,' p. 423.

$9 \quad S^{1}$, I, p. 273. 
kingdom - it seems that such ideas were not only viewed by Soloviev as compatible with the biblical view of creation but as fundamentally enhancing human understanding of the same. The gradual emergence of humanity through natural selection (a process which is given a typically Solovievian reworking), he argued, in no way detracts from humanity's favoured status as made 'in the image of God.' If the human being really is the 'crown of creation' and the end of God's work, as it is traditionally presented in biblical thought, the fact that the natural world arrived at a creature such as man through its own processes demonstrates, for Soloviev, that the conglomerate of such processes amounts to more than science acknowledges as the merely 'natural.'

Soloviev's argument and method on the question of humanity and its place in history proceeded from a dual foundation. Firstly, he looked at how humanity came into being in the historical context of evolution. Secondly, he attempted an answer as to what the human being is, its essential characteristics and attributes. It is the combination of these two perspectives, and the proximity of the answers he finds to the how and the what of human existence, that create the unique dynamics of his thought and produce the same curious tension between cause and result that we saw at work in his organic logic. Unlike Darwin, who by and large restricted himself to the formulation of evolutionary laws within the context of their direct operation, viewing the results of evolution as governed by the adaptability of a given species according to the laws of natural selection, the existence of humanity according to Soloviev is not dependent on the past; rather, the past is dependent for its momentum on the fact of the human being. That is to say, there is a teleology in prehistory which has such a creature as humanity as its inevitable goal; ${ }^{10}$ humanity is not the result of random mutations but, as Soloviev puts it in Lectures, 'the whole of nature aspired and gravitated toward the human being. ${ }^{\prime 11}$ The philosophical and theological question of the nature and vocation of human existence is thus itself historicized; its

10 In his preparatory notes to La Sophia, Soloviev writes: 'the world process is absolutely necessary and goal-oriented. Chance and arbitrariness exist only in human ignorance.' Rossiiskii Gosudarstvennyi Arkhiv Liteteratury i Iskusstva (RGALI), f. 446, op. 1, d. 40, p. 22 of 31.

$11 \mathrm{~S}^{2}$, II, p. 154. A similar idea has emerged in recent science-theology debate under the term the 'anthropic principle.' 
evolution in time is understood as the result of a guiding force operating within history. An answer to the question of what humanity is becomes bound up with the question of how it came to be.

The 'cosmic mind' as the guiding force of prehistory with which, in $\mathrm{La}$ Sophia, the figure of the Demiurge had been associated remained Soloviev's preferred term for the agent of the historical process throughout his career. ${ }^{12}$ But there was another term that was of equal, if not greater, importance. In his 'Lectures on the History of Philosophy' (1880-81), the philosopher connects this sense of an active force outside nature that directs and leads it with the gradual becoming of something within it, the object of transformation and evolution - the 'world soul.'

Nature is not only a senseless, material process but carries in itself an ideal content. The natural process itself, objectively considered as the world process, involves the gradual realization of an eternal content, the gradual birth of a natural idea, the world soul. ${ }^{13}$

The peculiarity of Soloviev's historical construct lies not in his conviction that the history of the world represents a teleologically oriented process, here described as the gradual birth of 'the world soul,' for such had been the view of any number of religious thinkers from antiquity to the present. It is rather in his particular approach to the question of agency in the world process that the uniqueness of his perspective consists. This approach is characterized, like his methodology, by a duality according to which the guiding principle of history occupies a position at once removed from the world process and, at the same time, fully integrated within it. The world, in Soloviev's thought, is both moved and mover; the progression of historical stages is just as much the bursting forth of the otherworldly as the culmination of its own, natural processes. Evolution and revelation are thus cohorts in the realization of world meaning. ${ }^{14}$ This combination of immanentalist

12 See particularly Soloviev's 1889 article 'Beauty in Nature,' in which the 'cosmic mind' and 'creative principle' (zizhditel'noe nachalo) of nature are allocated a major role in the world process. V.S.Solov'ev, Filosofiia iskusstva i literaturnaia kritika, ed. R. Gal'tseva and I. Rodnianskaia, Moscow, 1991, pp. 52-56.

13 V.S. Solov'ev, 'Lektsii po istorii filosofii,' Voprosy filosofii, 1989, 6, pp. 76-132 (p. 93).

14 Konstantin Antonov notes in this connection an 'interesting aporia' in Soloviev's thought: 'on one hand, he is required to show that Christianity is the logically 
and transcendentalist approaches is particularly evident in Soloviev's handling of the evolution of humanity.

Unlike those systems contemporaneous with him which, in the wake of geological evidence proving the earth was considerably older than the biblical literature supposed, had begun to view the border between history and prehistory as lying in that period when human civilizations first started documenting their existence through written records, Soloviev regards this border as the creation, or evolution, of humanity. When the first human being appeared on earth, there occurred, in his view, a monumental shift in the historical landscape; 'the cosmogonic process,' he writes, 'ends with the creation of the perfect organism - the human organism.'15

Soloviev presents the human being as the furthest point that organic life can reach by its own devices, that form beyond which it is impossible for it to progress. The creation of the world has reached its conclusion. That Soloviev regards the arrival of humanity on the world stage as the end point of cosmogony, in line with the so-called priestly account of creation found in Genesis 1 and yet sharply at odds with Darwinian theory, as well as modern geology and zoology, has several important implications for his system. Firstly, the creation of humanity, while located within the flow of time, becomes an unprecedented event in the evolutionary development of the world, after which can only come something entirely new, the beginning of a new process. Before the arrival of humanity, according to him, we can speak only of the cosmogonic process; after it, cosmogony gives way to history.

necessary culmination of the historical process and, on the other, to demonstrate its exclusivity as a 'new, unprecedented fact in the life of the world'. Countering the views of authors who believe Soloviev to have tied religious history too closely to natural causality, Antonov writes that the historical laws the philosopher outlines only 'fix the formal structure of the movement of this or that process while, like a mathematical equation, allowing him to replace the variable with the differing dynamic forces of these processes in different combinations. These forces do not obey a given law, but form it in their interaction. Likewise, the eschatological transition to the kingdom of the future age should be understood not as the result of the historical process [...] but its causa finalis.' K.M. Antonov, Filosofiia religii v russkoi metafizike XIX - nachalo XX veka, Moscow, 2009, pp. 117, 118. 
When, after many millennia of elemental and cosmic battle, in which the meaning of the world was revealed merely as a deterministic force of external law, there appeared the first rational creature, this was a new revelation - the revelation of the meaning of the world as an idea, in consciousness. ${ }^{16}$

For Soloviev, the newness that humanity represents in the world is precisely its rationality, the faculty traditionally used to separate humanity from the animal and plant kingdoms. But the philosopher understands reason not so much according to its common usage as a faculty innate to human beings, nor as a static instrument used to join together judgements and arrive at conclusions, but as a potentiality as yet unrealized that contains the seeds of its future actualization. Reason for him is 'the pure form of All-Unity,'17 the potential to contain within itself absolute content, or God. History begins only with the emergence of this reason in the world in the form of humanity.

Until the emergence of human consciousness, the guiding principle of being could only operate within nature as deterministic law. The great significance of human reason is that no longer does the teleological force of the world manifest itself for material objects as pure determinism. Instead, through human consciousness, it gains the potential of acting as the guiding principle of inner being, not only governing the external forms of the natural world but freeing the inner life of nature through humanity to participate in the realization of world meaning. After 'an external covering has been created in nature for the divine idea, there begins a new process in which this same idea is developed as the principle of inner All-Unity in the form of consciousness and free activity.' ${ }^{18}$ Evolution is here not arrested but acquires an interior dimension. The subject of evolution, the world soul, has found the organic form in which it can operate from itself, not as the mere longing we had previously observed in Soloviev's materia prima, but as the incarnate principle of free and conscious humanity. The latter, far from being subject to cosmic or cosmogonic activity, 'now not only participates in the activity of cosmic principles, but is able to know the goal of such activity and therefore to 
work knowingly and freely toward its realization.' 19 Thus, 'the meaning of the historical process (in contrast to the cosmic) is that it is conducted with the ever growing participation of individual agents. ${ }^{20}$

If this first aspect of Soloviev's anthropogeny has the effect of separating humanity from the created order, however, of seeing in its emergence an unprecedented act and a radical discontinuity from that which had come before, an equally strong second strand draws humanity once again toward nature and affirms it as an integral and inseparable part of the created world. This tendency is evident in Soloviev's middle period, and especially in the 'philosophy of biblical history' espoused in his monumental History and Future of Theocracy (1886). Here the tension between Soloviev's historical association of revelation and evolution is in clear view. If the creation of the human being can be understood as the end of cosmogony and the beginning of a new process, it should equally be seen as the cumulative outcome of the entire cosmogonic process - that for which all else was a preparation. There is thus a dual aspect to humanity in Soloviev's anthropological conception, a continuity and a discontinuity, an evolvedness and a fundamental newness. Seeing in Genesis $2.7^{21}$ a representation of this dual nature, he writes:

God creates the human being from the ground. Earthly nature is essential for it from the very beginning. It is not an accidental appendage but the constant foundation and matter of its life. Humanity is not immediately created from nothing. Being a creation of God as the active cause, it is alongside this a production of the earth as the material cause, and its essence in its dual composition can be called the earth of God (Bogo-zemlia). Humanity is thus, by his very origin, (genetically) linked with the material world. ${ }^{22}$

Both nature and God have an involvement in the phenomenon of humanity. Viewed from one perspective, God creates newness where before there had been only determinism, cause and effect. But from another perspective, nature fulfils her own vocation through

19 FI, p. 73.

$20 \quad \mathrm{~S}^{1}, \mathrm{I}, \mathrm{p} .256$.

21 'Then the Lord God formed man from the dust of the ground, and breathed into his nostrils the breath of life.'

22 SS, IV, p. 339. 
a kind of self-transcendence, by creating the conditions for another order of being apart from, but not over and against, the natural.

In the human being, nature outgrows herself and transitions (in consciousness) into the realm of absolute being. Perceiving and carrying in its consciousness the eternal divine idea, while at the same time inextricably linked to the nature of the external world in its factual origin and existence, humanity is the natural mediator between God and the material world, the transmitter of the all-unifying divine principle to elemental multiplicity, the builder and organizer of the universe. ${ }^{23}$

In such a way, Soloviev derives the essence of humanity's activity from human nature, or the fact of human being, itself. That which humanity is - namely, the creation of God out of the earth - defines the nature of its activity. As its being is defined by its dual aspect as both product of nature and creation of God, so its entire life is bound up in the mediation of these two, both in the inner life of consciousness and in the external life of material reality. To know how humanity should act, therefore, it is necessary to know what it is. Ethics is dependent on ontology. Indeed, Soloviev's ethical system is merely an extension of his ontology, a formulation of moral imperatives based not on the quality of the action itself as, for example, in Kant, but on the central phenomenological fact of human nature.

For Soloviev, humanity is above all this middle term between God and creation, the 'transmitter' of the divine to the material world. It is 'God's deputy on earth, so that in a certain sense God herself rules her earthly creatures through humanity alone.'24 But as this role in natural humanity only exists in potentiality - as an ideal given by reason - Soloviev's ontology becomes subsumed into history: what actually is turns out to be involved in a process of becoming. Here again we see the metaphysical, anthropological and cosmological dynamism that penetrates all of Soloviev's work. It is important to note, however, that, while in Soloviev's eschatology that which absolutely is only emerges in its fullness at the end of history, the preceding historical steps are not deprived of ontological status. Rather, these 
preliminary stages gradually lose their onesidedness and exclusivity as they become reintegrated into the totality of their connections to the whole. ${ }^{25}$ History does not undermine ontology by representing a series of illusory steps before the attainment of true being but, as a biologist reveals the ever-increasing complexity of interactions within a unitary organism, so history uncovers the layeredness of being, the interrelation of the parts of the one universe. We may prefer to say, therefore, that instead of that which is being subsumed into a process of becoming, in Soloviev's thought that which is becomes revealed as that which relates, and that which absolutely is is precisely the fullness of relation of everything to all, or All-Unity. The momentum of relation is the energy of history.

For history to reveal the interconnectedness of being in a series of progressive steps, or for it to strive toward the relatedness of all in all, this unity, argues Soloviev, has itself to exist prior to any given moment in historical time, for otherwise its teleological aspect, not having a goal before it, would be undermined. Before the human being, this unity could only operate on creation from without, as a blind striving for relation as such. The great significance of the phenomenon of reason, in Soloviev's view, is that this relatedness of all being now exists ideally within creation, in the consciousness of humanity.

For Soloviev, reason is the potential form for absolute content by virtue of the fact that it 'is a sort of correlation, namely the correlation of all in unity, ${ }^{26}$ the ability to contain within itself the totality of being in its interconnectedness. It is just this, though — an ability - since in itself 'it cannot have the creative force which belongs, for example, to will or fantasy.' ${ }^{27}$ Reason in Soloviev's thought may thus be described as the very power of relation, or the form of relatedness itself. 'Reason is a kind of relation (ratio) between things that gives them a particular form. But relation presupposes relating parties, form presupposes

'The positive link of the progressive kingdoms [i.e. plant, animal, human etc. - OS] can be seen in the fact that each type (the later they occur, the fuller they become) embraces or includes in itself those lower than it, so that the world process is not only a process of development toward an eventual perfection but also a process in which the universe is gathered together' (my emphases). S'1, I, p. 275.

26 PSS, III, p. 255.

27 Ibid., p. 367. 
content.'28 In other words, the faculty of reason demands a definite content; it cannot produce its own world but must work with the elements of the world in order to have effect. It must be the relation of something existent to something else. And since, as we have seen, humanity is by its very nature the mediator between God and creation, reason becomes the most quintessentially human of all abilities, that in which these two are mediated. 'The human principle is reason (ratio), that is, the relation of the divine and the material.'29

Already in Soloviev's conception of human nature, therefore, we have the seeds of human being's vocation: to use the relating power of reason to realize All-Unity, which exists in it as an ideal, in material reality. This ideal All-Unity, accessible to it through reason, is the trace of that radical discontinuity with the created order planted in humanity by God, and which Soloviev expresses by the biblical term 'the image of God.' The 'task' of humanity is to cultivate this image, or ideal, so that it may grow into its ultimate goal, rendered by Soloviev again in biblical terms as the 'likeness of God.'

The likeness of God in humanity or, more precisely, the likeness of humanity to God, is the actual realization of that image of God in which the human being was created and which was placed in it at the beginning. This ideal image, which is the innermost essence of humanity, does not depend on its will. The actual realization of this image, or assimilation to God, however, occurs not without the will and activity of itself humanity. ${ }^{30}$

Not only is history an outpouring of ontological reality through time, not only is the meaning of historical time the disclosure of this reality as relation, but humanity is called to be the agent of this process. It is to realise itself as 'the image of God,' to bring to fruition that which lies dormant within it as mere potential. In this way, Soloviev's ontology has as its direct result the formulation of the human being's ideal activity in the world, the task it must take on if it is to realise, and grow into, the fullness of its own, created being. 


\section{THE TASK AND THE KINGDOM OF GOD}

The connection between thought and action, expressed in Eastern Orthodox theology and Marxist philosophy by the term praxis, is fundamental to an understanding of the Russian religious and philosophical tradition. ${ }^{31}$ 'Theology without action,' wrote Maximus the Confessor, 'is the theology of demons.' ${ }^{32}$ When, therefore, in 1881 after the death of Fedor Dostoevsky, Soloviev spoke at the graveside of his friend of a great 'panhuman task' that was to unite all nations and peoples, he was not setting out on a new path but positioning himself in a long line of saints, thinkers and writers in the Eastern and Russian tradition who had insisted on the practical application of doctrine and theology and the unity of thought and action in Christian faith. ${ }^{33}$ Nor was this a diversion from his earlier, more unilaterally theoretical work, since the fixing and formulation of the 'first things' was always meant merely as a preparation for 'a spiritual building of the future,' as a justification of the task incumbent on humanity. To know what humanity should do, in Soloviev's view, one must know what it is, an answer to which question he sought in his early period.

On the face of things, as we have seen, this would seem to introduce a relatively straightforward dependency of ethics on ontology, at least as far as Soloviev's anthropological model is concerned. In human nature itself is the ground and condition for the task humanity is to realise. But as we have also argued, one of the peculiarities of Soloviev's thought lies in his conviction that the moment of being is revealed, in the life of humanity as well as in other spheres, in the process of becoming. Humanity's being is irrevocably connected to its historicity, its being in time. Viewed from this angle, action can be understood as

31 'All Russian religious philosophy,' writes Judith Kornblatt, 'insists on the role of action, a task or zadacha whose accomplishment will mean the reunion of God and creation.' J. D. Kornblatt, 'Russian Religious Thought and the Jewish Kabbala,' in The Occult in Soviet and Russian Culture, ed. B.G. Rosenthal, Ithaca, NY, 1997, pp. $75-95$ (p. 86).

32 Cited in Timothy Ware, The Orthodox Church, Harmondsworth, 1972, p. 215.

33 Many examples could be cited here of this general approach. Suffice it to say that the two literary giants of Soloviev's era, Dostoevsky and Tolstoy, diametrically opposed in so many respects, come together precisely in their emphasis on praxis, the practice and practicability of the Christian faith. 
the link between being and becoming of humanity, a sort of synthetic resolution of the two, for only in acting is the distance between them bridged. Through conscious acts, the human being reveals itself as the historical being par excellence, for action is the location of the present in the ever-moving area between a past of memory and the future of hope, a realization of the oneness of history through a conscious selfpositioning toward its ideal future. Soloviev writes:

The whole of history speaks of one thing and one thing alone: how collective humanity becomes better and bigger than its very self, how it outgrows its current present, moving it into the past while promoting to the present that which up to that very point had been something contradictory to reality, a dream, a subjective ideal, a utopia. ${ }^{34}$

This constant outgrowth of the present into the reality of a future imperative is the mark of the historical process, in which humanity incarnates the ideal in the real. Since the historical process is not only understood in Soloviev's work as a series of unrelated movements in time, each with its own goal and imperatives, but as a unitary and fundamentally logical process in which all ideals point toward a single destination, namely the Kingdom of God, human agency becomes the means of approaching the future consummation of all goals in an overarching narrative of fulfilment. To put it in theological terms, in conscious action humanity locates itself within salvation history. ${ }^{35}$

Soloviev's conception is here coloured by his belief that in such an orientation toward the final goal of the world and historical process, the gap between the individual human and collective humanity is overcome. In goal-oriented activity, the human being is not only the moving power of history, the sower of the future in the present, but also the unifier of his own, individual being with the rest of humankind through a commonality of direction. Just as Soloviev's

$34 \quad \mathrm{~S}^{2}$, II, pp. 613-14.

35 Notions of healing and salvation are deeply rooted in all of Soloviev's works, and his philosophy in general has an overwhelmingly soteriological thrust. In Spiritual Foundations of Life (1882-84), the most theological of his works, he portrays the meaning of history as 'the restoration of all in its absolute wholeness, or universal healing.' Solov'ev, Dukhovnye osnovy, p. 100. 
understanding of human nature was ultimately demonstrated to lie in relating - in an active and dynamic rather than static relation to being - so authentic human being, which for Soloviev is the collective life of humanity as a whole rather than the aggregate of its individual members, is revealed in human activity. ${ }^{36}$ Historical humanity discovers its unity in action, not stasis.

It is telling, therefore, that unity of confession, in this case Christianity, was never the task uppermost in Soloviev's mind. ${ }^{37}$ Instead, we find that unity is achieved not so much through a static state of being or belonging - be it personal conviction or confessional allegiance - but in the dynamism of the task itself. Human beings are not unified by membership in a group but by a shared vocation, a common task.

This task, i.e. authentic Christianity, is panhuman not only in the sense that it should unite all peoples in one faith, but above all in the sense that it should unite and reconcile all human affairs into one universal, common task. ${ }^{38}$

Although Soloviev does not explicitly conduct his argument here in terms of communion, its ecclesiological implications are clear. 'Being church,' just as being human, does not involve uniformity of constitution or doctrine but a shared sense of mission. It demands, he writes, 'complete unity of resolution, not homogeneity of life nor exclusivity of aspiration.'39

That such a unity between all members of humanity was possible, indeed more 'real' than its present condition of division, was an axiom of Soloviev's thought. It was from this perspective that he even went so far as to praise Auguste Comte's comparison of unified humanity to a great organism (Le Grand Être). See his article, 'The Idea of Humanity in the Thought of Auguste Comte,' in SS, IX, pp. 172-93. One may also mention the significant influence on him of the kabbalistic idea that God was constellated in human form (Adam Kadmon). Above all, however, it seems that the Pauline notion of the body of Christ remained central for him at least from his middle period onward.

37 This should be kept in mind when considering Soloviev's ecumenical work on the unification of the churches. Inter-denominational union was for him not a goal in itself but the provision of a sound basis for the realization of the task.

38 V.S.Solov'ev, Literaturnaia kritika, Moscow, 1990, p. 244.

39 SS, IV, p. 599. 
That Soloviev sees the task as synonymous with 'authentic Christianity' per se, rather than a particular aspect of Christian practice, gives us pause for thought. Unlike the task proposed by that other great Russian utopian, Nikolai Fedorov, which he straightforwardly described as 'the resurrection of the fathers' - the return to life of all those who have died-Soloviev's project from the outset displays an elusiveness that makes it difficult to arrive at any concrete articulation of its character. ${ }^{40}$ Unlike Fedorov's project, what Soloviev is speaking of cannot be exhausted by a stipulation of any definite action or behaviour. The task he is advocating, and continues to advocate for the rest of his life, is more even than a complex of practices, rituals or activities. It is best described as a form of praxis, understood in the theological sense, a combination of reflection and action that assimilates the human nature of the doer into the energy of its intention. This energy is the movement of history itself, understood not as the succession of one moment by another in a series of infinite degree, but as the becoming of the fullness of being. Soloviev's task is thus the realization of the very historicity of humanity, the discovery and conscious application of the role humanity is to play in the soteriological drama as ordained by its creator God from the beginning of time. Humanity is called to tune its own, human history to the goal of history, to locate itself within the entirety of historical time by tying itself, and the world, to salvation history.

It follows from here that the nature of Soloviev's task is best approached through the goal it serves, since it has value only insofar as it looks beyond itself to the ideal future and locates itself within

40 Despite this difference, there is clearly a great affinity between Soloviev's project and that of Fedorov. In 1881, Soloviev wrote to the latter: 'I accept your project unconditionally without the need for any further conversation.' In the same letter, Soloviev even proclaims Fedorov his 'teacher and spiritual father.' The great difference between the two philosophers, evident even in this first surviving letter, lies not so much in the formulation of the task itself as in the means required to achieve it. In a later, undated letter, Soloviev argues that 'the mere physical resurrection of the dead cannot be the goal in and of itself [...] Our task should have a religious not a scientific character.' Solov'ev, Pis'ma, II, pp. 345-47. Strémooukhoff argues that the decisive influence in Soloviev's emergence from what he regards as his early, predominantly theoretical period to the middle period with its emphasis on action belongs to Fedorov. See Strémooukhoff, Vladimir Solov'ev and His Messianic Work, pp. 135-36. See also S. Semenova, Filosof budushchego veka: Nikolai Fedorov, Moscow, 2004, pp. 115-25. 
a broader soteriological framework. This goal is associated throughout Soloviev's thought with the realization of the Kingdom of God which, in the face of all the formulations and reformulations we meet in his works, remains his dominant theological motif throughout.

The inner possibility, the main condition for union with God, can be found $[\ldots]$ in the human being itself - the Kingdom of God is inside us. But this possibility should transition into action, humanity should manifest the Kingdom of God concealed within it [...] The Kingdom of God is taken by force, and those who persevere shall possess it. Without these efforts, the possibility will remain mere possibility, the promise of future bliss will be lost, and the embryo of true life will waste away and die. And so the Kingdom of God, perfect in the eternal divine idea ('in heaven') and potentially inhering in our nature, is also necessarily something enacted for us and through us. From this perspective, it is our work, the task of our activity. ${ }^{41}$

The 'inner possibility' of the Kingdom of God is that same image planted by God in humanity of which we spoke earlier. The human being is called to know this image through reason, to recognise it in itself, and to work toward its realization through the attainment of 'likeness' to God. In the biblical language of the Kingdom, Soloviev moves away from an argument in which the task of humanity is portrayed as selfenclosed, as a matter of self-realization alone and nothing besides. The task involves not only humanity's assimilation to God through the attainment of her likeness, but that of the whole created order. The particular challenge of Soloviev's thought in this area lies in understanding how the Kingdom of God can appear to us in two different ways: as the goal of humanity, and as the eternal possession of God, for whom it exists in the fullness of its absolute manifestation. ${ }^{42}$ According to this view, if it is right to say that the image of God exists within humanity as a potentiality gradually actualized in history it is

$41 \quad S^{2}$, II, p. 309.

42 'For God and in God [...] the Kingdom of God is already created [...] the entire hierarchical construction of the universe in all its complex perfection, all the depths of true knowledge and the entire fullness of the living and sacramental interaction between God and creation, all this three-part whole exists as one perfect, concrete in all its parts, and immaculate organism of God's creation (bogotvorenie) or the body of God.' Solov'ev, Dukhovnye osnovy, pp. 110-11. 
equally the case that its final, exterior manifestation already exists outside humanity, as perfected in God. Recalling the words of the Lord's Prayer, Soloviev writes:

We do not say may your Kingdom be created but may your Kingdom come. Only something that already is may come. The Kingdom of God in itself already is, for everything is subject in its essence to God Almighty. But we should wish that the Kingdom of God was not only over everything, which it already is, but that God was all in all and that everything was one in Her. ${ }^{43}$

We are to speak, then, not of the creation of the Kingdom of God, for the Kingdom already is, but of humanity's involvement in an historical process in which the Kingdom 'comes.' In fact, for Soloviev it is not permissible to speak of the Kingdom as a created thing at all, whether by God or humanity, since it is 'not some object separate from other objects. It is their true constellation (ustroenie) in which nothing harms another and nothing is lost. ${ }^{4} 4$ The Kingdom is not objectified being but rather being that has transcended itself in relation, the relatedness of all in God. It is a form of being whose character is disclosed not primarily by its content, the multiplicity of its components, but by the way in which these components relate to one another. The task, therefore, is not 'to build and tear down,' nor to add to the content of being, but to break the isolation of being by relating all to God, by conforming our discontinuous present to the eternal continuous. To stress again: this relatedness of all in God already exists in and for the eternal God in all the complexity of its interaction between history and eternity, but it is necessary that it should exist in and for historical being itself. It is not enough for Soloviev that the Kingdom of God already extends over all things. The divine rule must operate within the inner life of all things, not only that of humanity; it must manifest itself from within the whole creation as the law of its own being in time. The transcendence of the Kingdom which rules over all things must become immanent in history. 45

$43 \quad$ Ibid., p. 37.

44 The soteriological element is again to the fore here. Compare with John 6.39: 'And this is the will of him who sent me, that I should lose nothing of all that he has given me, but raise it up on the last day.'

45 Ignacio Ellacuría has written in a similar vein of 'the unavoidable need to make the Kingdom's transcendence historical' in the context of his own liberation theology. 
Intimately connected to this gradual realization of the Kingdom within history, there is, as we have seen, another process in Soloviev's thought, in which the interiority of the Kingdom to humanity gradually acquires an externality in the space of creation. The realization of the Kingdom thus becomes a process conducted from two centres: one in which the transcendence of God manifests itself in history, or in which the God of eternity becomes the God of history; and the second in which the Kingdom inside humanity transforms both human nature and the material world. The first process, in which the transcendence of the Kingdom is historicized from the locus of the transcendent, and which is properly the activity of the divine, is denoted in Soloviev by the term 'materialization of spirit' (materializatsiia dukha). The second is connected with ctivity of human and expressed by the term 'spiritualization of matter' (odukhotvorenie materii). Together they express the totality of the divine-human (bogochelovecheskii) process which, while from the perspective of God is complete and perfected, from the perspective of historical humanity is expressed as a task, the object of its efforts.

Humanity is to actualize in history what, for God in eternity, is given. It should again be stressed that this cannot mean creation, or activity directed toward a definite object. Rather, Soloviev understands it as a conforming of the two Kingdoms, that within humanity and that which transcends it. "There is the Kingdom of God inside us and the Kingdom outside us. The agreement (sovpadenie) of the one and the other, the complete dissolution (rastvorenie) of the inner Kingdom of God with the external Kingdom is the goal of our activity. ${ }^{36}$ Humanity is thus involved in a double process of correlation, the conscious bringing of its own nature into 'likeness' with God, and the externalizing of that likeness in the world around it. The realization of the Kingdom of God is not merely, therefore, the actualization of the innermost core of humanity, the image of God, but alongside this and just as strongly the extension of the rule of God, or theocracy, to all created being. ${ }^{47}$

See I. Ellacuría, 'Utopia and Prophecy in Latin America,' in Mysterium liberationis: fundamental concepts of liberation theology, ed. I. Ellacuría and J.Sobrino, New York, 1993, pp. 289-328 (p. 294).

46 SS, IV, p. 591.

47 'The Kingdom of God has not only an inner dimension in the spirit, but also an external dimension in power. It is a real theocracy.' S², I, p. 226. 
The transformation of its own nature and the transformation of the world are the two complementary and mutually conditioning aspects of humanity's task, and the basis of Soloviev's soteriology.

Humanity's cooperation with God in this task of universal healing should consist in the gradual, free and conscious transformation of carnal life within itself and outside itself into spiritual life: the materialization of spirit and the spiritualization of matter, the reunion of the two principles on whose division carnal life is based. ${ }^{48}$

Recalling Soloviev's formulation of the dual nature of humanity as 'the earth of God,' the indwelling of divine spirit in earthly matter, and the characterization of the human's vocation as the ideal correlation of these two, the task is understood to go beyond its merely ideal aspect (as realised within the interior space of human consciousness) and incorporate the external, natural world. This breaking out of human interiority itself requires a new revelation, and it is to this new revelation that we now shift our attention. Viewed from another angle, however, the unity of humanity and the natural world in the salvation history of the world is but an extension of Soloviev's view on the evolvedness of humanity, its continuation of the process initiated in prehistory rather than its radical intervention in the same. By virtue of humanity's continuity with the cosmic process, the same process that had begun with the creation of the world continues in humanity, itself a product of the earth. The spiritual dimension of its activity does not stand against the 'carnal' world of matter, but draws it into itself, transfiguring and spiritualizing it. In this sense, humanity is as much the bearer of the natural principle as it is the divine idea. Just as with the emergence of the human being the transcendence of the spirit was first embodied as potential in history, so through humanity's development in history the isolation, or non-transcendence, of the material principle it carries within itself is spiritualized and drawn into the realm of divine being. History is a continuation of cosmology. ${ }^{49}$ It is Soloviev's insistence

$48 \quad$ PSS, III, p. 162.

49 Sutton points to Soloviev's conviction that the 'cosmic process itself is intimately connected with the historical process.' Sutton, The Religious Philosophy of Vladimir Solovyov, p. 67. 
that 'there is no gulf between the real essence of spiritual and material nature, that the two are most intimately connected and constantly interact, 50 that provides his anthropological vision with its dynamic structure and irreducibility to a single principle. In humanity matter and spirit meet, and in history the two are conformed to each other through its conscious activity. The material structure of the world, which in humanity transitions into potential likeness to the spirit of God, is itself brought into this movement, and participates in the liberation and healing from the isolation of carnal life which is gradually realized in history. Humanity and world in Soloviev's thought are thus geared toward a common goal - the realization of the Kingdom of God.

\section{CHRIST THE GOD-MAN}

Soloviev's Lectures on Theanthropy (1877-81) represent a watermark in his early work not so much because of the emphasis he places on the person of Jesus Christ - his entire metaphysics from the earlier work so coloured by Gnostic influences to his late Short Story of the Antichrist (1900) has a profound Christological basis - but because of its refocusing of Christology away from metaphysical speculation as to the second person's perichoretic function within the godhead toward the nature of Christ's activity in history. This is not to say that Soloviev was interested in the historical person of Jesus, for he seemed least of all concerned with this. ${ }^{51}$ Rather, in Lectures and the works of biblical exegesis that follow it, Soloviev's central problematic becomes the historicization of the transcendent God, which finds its culmination in the Incarnation, and the articulation of humanity's ideal response to this prior action on the part of the divine. Christ in Soloviev's thought is important not in the precise character of his appearance in history, nor in what he taught during his life, but insofar as such

$50 \quad$ PSS, III, pp. 157-58.

51 Soloviev had nothing but contempt for the, at that time, new trend of historical criticism in biblical studies. "We proclaim nothing but the authenticity of the biblical story in its general characteristics and in no way the pedantic precision of biblical chronology and statistics,' he wrote in History and Future of Theocracy. SS, IV, p. 422. 
a phenomenon appeared at all, and its implications for humanity and world. The significance of Christianity lies not in its doctrine or its theology, which though important would make of the religion, if these were its only fundamental characteristics, an eclectic system alongside other systems, but in the person of Christ himself.

Christianity has its own content, independent from all the elements of which it consists, and this content is solely and exclusively Christ. In Christianity as such we find Christ and only Christ. Here is a truth repeated many times but very poorly understood. ${ }^{52}$

Just as the emergence of the first human on the world stage was for Soloviev an event of unparalleled newness signifying the potential attainment of the absolute idea through reason, so too the Incarnation represents an act utterly unprecedented in history.

When after many millennia of human history there appeared the first spiritual human, in whom the natural life of the flesh was not only illumined by the divine meaning of the life of the world but illumined by him as the spirit of love, this was a new revelation of that same meaning [to have become embodied in humanity as an idea] as a living personal power able to attract to itself and harness the living force of matter. ${ }^{53}$

Once again we notice the same combination of revelation and evolution, discontinuity and continuity, that we saw in Soloviev's treatment of the creation and evolution of the human being. In Jesus Christ, the 'first spiritual human,' creation steps into a new phase of its history; a newness is now present that is irreducible to the history of its appearance. And yet there is also an evolvedness in Christ, as there was in Soloviev's picture of humanity, not in the sense of creatureliness, for Soloviev's Christology never arrives at a direct association with the created order, but in the sense that the Incarnation for him represents the culmination and flowering of the entire historical drama up to that point. As he writes, 'the historical appearance of Christ [...] is indissolubly connected to the entire world process, and with the denial

$52 \quad$ S2, II, p. 105.

53 Solov'ev, Dukhovnye osnovy, p. 87. 
of this appearance the meaning and directionality of the universe are lost. ${ }^{.54}$ As the new dimension of human consciousness arises from the unconscious attempts of nature to transcend itself, so the newness of Christ emerges from the self-transcending movement of humanity in history. "The whole of nature aspired and gravitated toward the human; the whole of human history was directed toward the Godman. ${ }^{55}$ God in Christ is thus understood not as a deus ex machina intervening in history, but as intimately bound to the entirety of the historical life of his creation.

It is not the transcendent God who becomes incarnate in Jesus, that is to say, that which is incarnated is not the absolute, self-enclosed fullness of being (which would be impossible). Rather, it is God the Word, a principle which manifests itself outwardly and is active on the periphery of being. Its personal incarnation in an individual human is only the last link in a long series of incarnations, both physical and historical. This appearance of God in human flesh is only the fullest, most perfect theophany in a series of other incomplete preparatory and transformative theophanies. ${ }^{56}$

We have discussed the emphasis Soloviev places on the historicization of the transcendent in a general salvific landscape that is directed toward the coming of the Kingdom of God. Here, though, it appears he is directing his reader away from an understanding of transcendence qua transcendence as the fundamental characteristic of the divine and toward a re-envisioning of the divine nature. While leaving a space, at least conceptually, for God's transcendence, he suggests that the fullness of the divine nature cannot be grasped in isolation, but only when manifested outwardly for the other. The Christian God is portrayed not primarily as the transcendent one become historical, nor even the historical one become transcendent, but eternally the union of the one and the other in and through Christ. God is intimately connected to her creation in a way that eludes a linear conception of her saving acts in process.' See $\mathrm{S}^{2}$, II, p. 500 .

$55 \quad \mathrm{~S}^{2}$, II, p. 154.

56 Ibid., p. 154. 
history; she is eternally the 'beyond in the midst of life,' to use Dietrich Bonhoeffer's phrase. ${ }^{57}$ Life, not transcendence, is the characteristic that defines God as such.

In Soloviev's preferred terms, the divine is not only involved in the materialization of spirit but equally in the spiritualization of matter; God operates not merely from within eternity but just as strongly from within history. ${ }^{58}$ And it is precisely in the person of Christ, in whom 'the whole fullness of deity dwells bodily,'59 that God forms a unity of these two distinct activities which, though separable by reason, are eternally one. Christ has 'from the centre of eternity become the centre of history'; the two are united, although not conflated, in the God-man. It is from this perspective that the enthusiastic advocate of the Russian sophiological tradition, John Milbank, comments that 'from eternity God has always been the God-Man and the Russians are right: the theanthropic exceeds even the theological.'60

57 'God's "beyond" is not the beyond of our cognitive faculties. The transcendence of epistemological theory has nothing to do with the transcendence of God. God is beyond in the midst of our life. The church stands not at the boundaries where human powers give out, but in the middle of the village.' D. Bonhoeffer, Letters and Papers from Prison, New York, 1971, p. 282. Bonhoeffer's reflections on the transcendence of God draw him very close to Soloviev. Like the latter, the German theologian suggests that we do ill to confuse the epistemic transcendence of the divine, God's inscrutability to our cognitive faculties, with God's actual self-transcendence to both history and world.

'Life in general,' wrote Soloviev, 'is the unification of the spiritual principle with matter, or nature, the incarnation of spirit, the spiritualization of matter.' The dual process through which spirit and matter unite, therefore, is the mark not just of God but of life itself. S2, I, p. 80.

59 Colossians 2.9 .

60 J.Milbank, 'Sophiology and Theurgy: the New Theological Horizon,' The Centre of Theology and Philosophy: Online Papers, University of Nottingham (2007), <http://www. theologyphilosophycentre.co.uk/papers/Milbank_SophiologyTheurgy.doc> [accessed 16 June 2008] (p. 54 of 64). Brandon Gallaher writes: 'God's being is always already enacted in Christ as the divine organism (Logos and Sophia) and therefore whatever exists in creation exists in and by Christ because it is a moment of the one divine Christoform action of God's eternal self-realization as Sophia.' B.Gallaher, 'The Christological Focus of Vladimir Solov'ev's Sophiology,' Modern Theology, 25, 4, 2009, pp. 617-46 (p. 628). We should also note the comments of Anthony Baker and Rocco Gangle (on Bulgakov, though just as applicable to Soloviev), which seem to sum up the essence of sophiology: 'the Christian God (in contrast to the Plotinian One) is, "prior" to any question of creation, always already a God in relation. The "absolute" is always already the "absolute-relative"; not simply internally relational as Trinity, but also, 
For Soloviev, indeed, theanthropy exceeds theology, and in the person of Jesus Christ, the God-man, we find the central interpretative paradigm of his philosophy of All-Unity and the active principle in his concept of bogochelovechestvo. In Christ, he sees not just the historical appearance of the eternal God of spirit but also the fulfilment of humanity. In the latter the ideal relatedness of all things was first attained as an idea in the relating power of reason. But 'that unity in which the universe is sustained and connected cannot remain merely an abstract idea. It is the living, personal power of God, and the all-unifying essence of this power is revealed to us in the theanthropic person of Christ.'61 Human consciousness and its quintessential attribute, reason, represent the potential ability to grasp the interrelation of all in God, the power to grasp the interconnectedness of the universe. But this All-Unity, even when attained, remains and is destined to remain within the confines of human consciousness which, as form, may contain the fullness of the divine and material realms yet remains powerless to realise this fullness outwardly in the world around it. The interiority of the Kingdom to humanity cannot overcome its interiority by its own means. In this, then, is the purpose of the Incarnation in the Solovievian conception: for the divine to unite with humanity in such a way that its inner life no longer stands over and against the external life but is released, so that the image of God which grows within it may, in the words of another biblical passage, 'pour out on all flesh' and become incarnate in the material world. ${ }^{62}$

The God-Man, or existent reason (Logos), not only understands the meaning of all in the abstract but realises it in reality [...] The highest task of humanity as such (pure humanity) and the purely human sphere of being is to gather the universe in the idea; the task of the God-man and the Kingdom of God is to gather the universe in reality. ${ }^{63}$

and by virtue of this, relating as a Godhead to an "imaginary" exteriority, to a beloved companion who springs from the love that is the intrinsic essence of God himself.' A. Baker and R. Gangle, 'Ecclesia: The Art of the Visual,' in C. Davis, J. Milbank and S.Žižek (eds), Theology and the Political: The New Debate, Durham and London, 2005, 267-80 (p. 273).

61 Solov'ev, Dukhovnye osnovy, p. 21.

62 Joel 2.29.

$63 \quad S^{1}$, I, p. 275. 
The ideal relatedness of all in God which for the first time in history acquired reality, at least potentially, in man's faculty of reason - the 'correlation of all in unity' - now finds itself 'existent' not only interiorly but outwardly, in concrete, material form. While Soloviev assigns the task of relating the fractured and fractious components of the universe together interiorly through reason to humanity, the particular mission of Christ, and the Kingdom he proclaimed is to do so in reality. ${ }^{64}$ No longer is the divine contained within human consciousness alone, but in the first 'spiritual human,' Christ, it takes on flesh and is born in matter.

Alongside this, however, we must hold to the understanding that for Soloviev the Incarnation does not stand in opposition to the development of human consciousness or negate the previous development of the natural world. The Incarnation is viewed in his work both as God embarking on a new process within history, and as continuing the process that began with the creation of the world and continued through the emergence of the human organism. In line with Orthodox teaching, Soloviev sees the Incarnation as the adoption of the fullness of human life, not just its semblance. Christ is both man and God, and must himself experience the presence of the Kingdom as it is to God 'in heaven,' as well as its interiority to humanity 'on earth.' This demand carries with it certain ramifications. For God to experience the interiority of the Kingdom means for her to experience the split between inner and external life, to become located within a context in which the limits of consciousness are concretely felt.

The divine principle here is not enclosed only by the confines of human consciousness, as it was in previous, incomplete theophanies, but itself takes on these confines. It is not that it has entered completely into these confines of natural consciousness, for this would be impossible, but that it feels these confines in actuality as its own at any given moment, and this self-limiting of God in Christ frees His humanity, allowing His natural will to surrender freely itself to the divine principle not as an external power (for such a self-renunciation would not be free) but as the inner good (blago vnutrennee), and thus to actually attain this good. ${ }^{65}$

64 For Soloviev, 'the Gospel of Christ is the Gospel of the Kingdom. Christ begins his ministry with the good news about the nearing of the Kingdom, the nearing of something new, unprecedented.' SS, IV, p. 591. S², II, p. 157. 
It is Christ's self-experience of the interiority of the Kingdom, Soloviev is arguing, that makes room for his full humanity and thus freedom, for if the split between inner consciousness and external life were not concretely experienced, his humanity would be unable to freely conform itself to the Kingdom that lies outside, such a distinction no longer having a basis in reality. This conforming of inner consciousness to God's Kingdom is made perfect in Christ insofar as He is able to allow himself to be completely defined by the divine principle, bringing His humanity into full correlation with the presence of God within it since he is, in himself, the absolute union of the two. What is revealed in Christ is thus 'the infinitude of the human soul, able to fit within itself the entire infinitude of God.' 66 In Christ human nature for the first time transcends the limits of its finitude, the self-confined interiority of the Kingdom, and is shot through with divinity. The humanity of Christ is 'spiritualized' or divinized not despite his humanity but because of it.

Since the fullness of Christ's humanity meant for Soloviev that he had to enter fully into the human experience and to feel the 'confines' of human consciousness as his own while remaining fully God, this experience necessarily presupposes a process of becoming in time. If we are to speak of the Incarnation as the divine interceding in history through Christ, therefore, we must also speak of the mission of Christ. In his divine aspect, Christ is God incarnate but in his humanity he is necessarily involved in conforming this humanity to God. The Incarnation is consequently not the resting point for Soloviev's conception of the God-man, since to understand Christ solely from an incarnational perspective is to arrive at precisely the kind of static and unidimensional Christology he was trying to avoid. If Christ puts on humanity, he argues, he puts on temporality and becoming: not virtually or seemingly, but actually and concretely. Like humanity, then, Christ has a task to realise on earth, namely the conformation of his humanity to the divine. The culmination of this earthly mission for Soloviev is the Resurrection. Viewed from this perspective, the Christevent, seen as a theanthropic whole, encompasses incarnation and resurrection, each effective toward a singular purpose. 
Only in the Incarnation and Resurrection of the God-man does natural being in the form of the human organism first fulfil its infinite ambition, gaining for itself the fullness and integrality of divine life [...] It is not in the death of the natural individual that the world's contradiction between the personal and the general is resolved but in its resurrection and eternal life. And this resolution is attained through the rational and free activity of the human will. The condition for resurrection is a personal feat (podvig), that act of the rational human will with which Christ renounced the law of sin and became obedient to the absolute will of God, making the principle of His humanity a channel for divine activity on the material world. ${ }^{67}$

Note here Soloviev's insistence on the participation of Christ's human will in the fulfilment of his earthly mission. Yet it is not that this will participates in the act of resurrection itself, but rather that it constitutes for Soloviev the 'condition for resurrection,' becoming the ground, or channel, for the divinity that becomes manifest therein.

Running alongside this, and most striking of all, is the historical picture painted by the philosopher. In a few words, he summarizes the main points of our survey thus far. As nature outgrows, or selftranscends, itself in humanity, so humanity outgrows itself in Christ. Just as the natural world reaches its fullest development in human, the perfect natural organism, so humanity realises its fullest potential in the God-man, both the perfect natural and the perfect spiritual organism. Important here, to put it in spatial terms, is once more the locus of transcendence. That which is transcended is transcended not from a position outside itself but from within. Transcendence here is not the result of a transcendent subject acting from without on a non-transcendent object but a subjective process, a growing outwardly from a prior position of limitation. Thus Soloviev can write of 'natural being in the form of the human organism,' for humanity is both the bearer of nature per se and a nature transcendent, or the human principle as such. In a similar way, Christ is both the bearer of humanity and a humanity transcendent, a normative humanity and a spiritualized, or 'glorified,' humanity. As cosmology grows into anthropology, Soloviev's anthropology now grows into Christology. 
Humanity does not negate the natural principle but realises it, bringing it to the goal of its strivings and adopting it within itself, transforming while preserving it in its integrity. Likewise, Christ takes humanity and bears it in himself, transfiguring but at the same time integrating and preserving it. In his transfiguration of human nature, both the human principle and the natural principle with which humanity is inextricably bound are brought into the movement of the God-man.

As we saw in the section on anthropology, Soloviev derives the task of humanity in the world from human nature itself: the dual nature of the human being as 'the earth of God,' both natural and divine, resulted in the formulation of task as the mediation of these two principles, the materialization of spirit and the spiritualization of matter. That which humanity is, namely the unity of matter and spirit, it is called to realise in itself and the world around it. This unity was further defined as the ideal interrelatedness of all in God, potential access to which was first achieved in the world through the emergence of human consciousness and its faculty of reason. Reason becomes the great relater, the ability to contain within itself the complex interrelatedness of being, and the task of humanity to use that reason to 'gather the universe' in its ideal dimension.

Yet the unique significance of the person of Christ in Soloviev's thought does not lie in his ability to use reason to relate the elements of the world together in the ideal space of human consciousness, but to do so in reality. Borrowing from and developing the Logos theology of John's Gospel, Soloviev uses the terms 'Word made flesh,' 'Meaning made flesh,' 'realized Logos' and 'existent reason'68 to give voice to his conviction that in Christ that which exists interiorly to humanity as the potential of absolute content has become externalised in concrete, material form. That very relating power of reason, 'the correlation of all in unity,' the essential characteristic of the human being, itself speaks, moves and acts through the person of Jesus Christ.

The theologian Karl Rahner described Jesus Christ as 'a man in whom reality does not lag behind the demands of human nature.'69 In Soloviev's thought, Christ is the perfect human precisely insofar

$68 \quad$ S$^{2}$, II, p. 169; PSS, II, p. 281; S1, I, p. 275.

69 K. Rahner, The Practice of Faith, London, 1985, p. 8. 
as there is no gap between his being and his nature, between what is demanded of him as fully human and what he fulfils in reality. ${ }^{70} \mathrm{He}$ is the ideal relatedness of spirit and matter in one body and one soul. And yet this does not mean that his humanity is conformed to God, the ideal, through divine fiat but rather, as Soloviev writes, through 'a personal feat,' 'an act of the rational human will.' He fulfils his mission through his humanity, not despite it.

Even so, Soloviev simultaneously asserts that the divine is only able to operate from within humanity in Christ insofar as His rational human consciousness is able to renounce itself freely and become obedient to the absolute will of God. Although rarely stated explicitly, the idea of kenosis, which in the Christological tradition dates back to the Pauline epistles and refers to Christ's 'self-emptying' both in the Incarnation and his earthly life, stands central to Soloviev's theology. Its further development lies in the philosopher's reworking of the concept of the 'body of Christ.'

\section{THE BODY OF CHRIST}

Many of the most important concepts from the early part of Soloviev's middle period are taken from the Bible and early Christian thought, whether orthodox or heterodox, ranging from the 'image' and 'likeness' of God to the 'Kingdom of God' and the church. But there is one particular writer within that context whose mark is writ large over all of Soloviev's thought from Lectures on Theanthropy onwards, and that is the Apostle Paul. Other than the cases in which Soloviev explicitly points to Paul as the original source for the content of his thought, ${ }^{71}$ the Christological language he employs is often directly taken from Paul's writings. ${ }^{72}$ The most important of these borrowings is that most

70 In the Confession of Chalcedon, this idea was expressed by the words 'in all things like unto us, without sin.'

71 See, for example, S', I, p. 96.

72 The singularity of much of Paul's language puts the question of the source of these borrowings beyond question. 'To clothe yourself with Christ' (Galatians 3.27), 'to grow into the full stature of Christ' (Ephesians 4.13), 'that Christ may be formed in all' (Galatians 4.19) are all Pauline idioms that occur practically word-for-word in Soloviev's discourse. 
significant of Pauline concepts - the body of Christ. ${ }^{73}$ Christ's body, in the sacramental life of the church and the growing body of collective humanity, becomes the new subject of history after the Incarnation, and it is in and through this body that salvation from death and decay is to occur.

Considering the centrality of Soloviev's Christology to his interpretative framework, it is tempting to conclude that an overarching Christocentrism characterizes his philosophy as a whole. ${ }^{74}$ To arrive at such a conclusion, however, is to fail to recognize how far Soloviev actually moves away from a more traditional Christocentric model, in which the second person of the Trinity appropriates the distinctive character of the first and third persons and post-incarnational history is relegated to a mere afterthought in the life of the universe. ${ }^{75} \mathrm{In}$ contrast to such thinking, the Russian philosopher, while affirming the centrality of the Christ-event to the historical life of the world, argues that the death and resurrection of the God-man mark not the end point of salvation history but the beginning of a new process in which humanity is to be actively involved. ${ }^{76}$

Christ came into the world not to enrich its life with a few new ceremonies but to save it. With His death and resurrection, He saved the world in principle, at its root, at its centre. The expansion of this salvation to the entire circle of human and earthly life, the realization of

John Robinson writes that 'one could say without exaggeration that the concept of the body forms the keystone of Paul's theology [...] It is from the body of sin and death that we are delivered; it is through the body of Christ on the Cross that we are saved; it is into His body the Church that we are incorporated.' J. A. T. Robinson, The Body: A Study in Pauline Theology, London, 1966, p. 9.

74 Paul Allen describes Soloviev's brand of mysticism, from which derives his philosophy, as 'Christocentric in the highest degree.' Allen, Vladimir Soloviev, p. 288.

75 In contemporary Christian theology, Karl Barth's term 'christological concentration,' while intended to avoid a hierarchical understanding of the Trinity rather than advocate one, has led to some confusion. Amongst others, Jürgen Moltmann has been keen to avoid its Christocentric implications by developing a pneumatological theology of creation alongside other, more traditional Christological interpretations. See especially Jürgen Moltmann, God in Creation: An Ecological Doctrine of Creation, London, 1985.

76 'Soloviev,' writes Dmitrii Krylov, 'clearly proceeded from a trinitarian rather than Christocentric understanding of history'. Krylov, Evkharisticheskaia chasha, p. 177. 
the principle of salvation in all of our reality: this He can do not alone, but only together with humanity itself, for no one can actually be saved by force or unwittingly. ${ }^{77}$

Despite this insistence on the non-finality of the Christ-event and the continuing presence and action of the divine Word in history, Soloviev is extremely careful not to cast doubt on the efficacy of the saving act of God through Christ. To understand his position more fully, it may be helpful to employ two terms recently advanced by the French theologian Jacques Dupuis. Dupuis writes of 'the qualitative plenitude' of God's revelation in Christ - its unsurpassable nature and significance for the world and humanity - while at the same time speaking of another, as-yet-unrealised fullness, which he describes as 'quantitative.' He argues that, qualitatively, the salvation that came through Christ cannot be surpassed by future revelation but represents soteriological consummation in its most intense and concentrated essence. The salvation whose inner core revealed itself in Christ, however, has not yet spread itself across all creation; its quantitative breadth awaits its full realization. ${ }^{78}$

Soloviev, like Dupuis, was faced with the problem of finding meaning in a post-incarnational world in which, despite the Incarnation, divine truth had not yet been realized in the whole of creation. The terms he uses to justify his conviction in the enduring meaning of history, affirming both the efficacy of the Christ-event in the context of salvation history yet at the same time its relativity to the historical present, share much with those of the French theologian. Soloviev writes that the God-man saved the world 'at its centre,' opposing this to a salvation that encompasses not only the centre but the 'periphery'

77 S2, II, p. 349. Comparing Solov'ievian 'messianism' with the 'accomplished messianism' of the Jewish historian Joseph Salvador, Strémooukhoff argues that the difference between the two lies precisely in the former's deferral of the fullness of salvation in Christ to a future time: 'the God-Man, it is true, has already been incarnate, but a universal and collective man-God must still be formed, a God-Manhood which will at the same time be the universal Church.' Strémooukhoff, Vladimir Solov'ev and His Messianic Work, p. 100.

78 See especially J. Dupuis, 'The Truth will Make you Free,' Louvain Studies, 24, 1999, 3, pp. 211-63 (p. 235); Toward a Christian Theology of Religious Pluralism, Maryknoll, NY, 1997, pp. 296-97. 
of being. ${ }^{79}$ His soteriological conception is fundamentally synchronic as opposed to diachronic; salvation here is understood not so much according to a linear conception of time as the qualitative intensity of its historical manifestation. The soteriological contours of Soloviev's philosophy are thus plotted within a circle rather than along a line, with Christ as the centre in which all points cohere. But the very coherence of all points in him is precisely that which awaits realization: qualitatively, Christ was, is and will remain the centre of universal salvation; quantitatively this salvation must possess the entirety of being so that, in Soloviev's favoured words, God becomes 'all in all.'

Although Christ irrevocably defeated evil at the genuine focus of the universe, i.e. in Himself, the overcoming of evil on the circumference of the world, i.e. in the collective whole of humanity, must be attained through the self-experience of humanity, for which a new process is required whereby the Christian world, baptized into Christ but not yet clothed in Him, is to develop anew. ${ }^{80}$

This opposition between the ultimate defeat of evil in the person of Christ, the 'focus of the universe,' and its defeat at the 'circumference of the world' in collective humanity is central to Soloviev's envisioning of the task of humanity within a Christian context and is connected to his particular understanding of the nature of evil in the world. For him, evil, and its corollary suffering, lies in the will to self-affirmation to the exclusion of all else, in an egoistic impulse that governs human hearts and the elements of the natural world alike. ${ }^{81}$ In 'Lectures on the History of Philosophy,' he writes:

'This, i.e. particularity, which within the whole (in God) exists in positive unity with all, is the idea. For each separate creature, this idea is

79 As Ruth Coates has pointed out, the metaphor of the circle, and the relationship between centre and periphery, contains strong echoes of Neoplatonic thought, in particular Plotinus. See R. Coates, 'Mystical Union in the Philosophy of Vladimir Solovev,' in J. Andrew, D. Offord, R. Reid (eds), Turgenev and Russian Culture: Essays to Honour Richard Peace, Amsterdam, 2008, pp. 135-56 (p. 139).

$80 \mathrm{~S}^{1}, \mathrm{I}, \mathrm{p} .280$.

81 'Evil is that concentrated state of will that affirms itself alone and negates every else. Suffering is the necessary reaction against this sort of will, a reaction to which the self-affirming creature yields involuntarily and inevitably and which it feels precisely as suffering.' S², II, p. 123. 
something exclusive, not encompassing but shutting out everything else. This external relationship of each to all makes up the order of material, peripheral being that exists in time and space. ${ }^{82}$

The 'peripherality' of material being here adduced by Soloviev lies in its non-centredness in God, according to which each particular ('this') finds itself in opposition to the whole rather than in the unity of the some. Soloviev here writes of particularity as 'the idea,' that form or principle in which God created the world. This idea exists in unity with all in God whereas on the circumference of being, or outside God, it persists in isolation. The concrete expression of this isolation is the very materiality of the world, centred in itself rather than God and closed to the influence of the other. ${ }^{83}$ The significance of the Incarnation and Resurrection for Soloviev is that 'the contradiction between the personal and the general,' individual and universal, spirit and matter - the hitherto irreconcilable poles of universal life - are resolved in the person of Jesus Christ: the God 'in whom all things cohere' becomes a particular individual with a history in a concrete time and place. It is because Christ is incarnated in the particular as 'a living personal power' that he is not only the dwelling of the idea in matter, the assertion of the oneness of spirit and matter, but the active transformer of the material stratum of his own personality - his body - into a direct and immediate expression of his inner life which, rather than standing over and against other bodies, is open to the influence of the other. ${ }^{84}$ The end point of this process is the Resurrection.

The spiritual principle in its very victory over hostile nature must show its superiority, not destroying or devouring this vanquished nature but restoring it in a new, better form of being. Resurrection is the inner reconciliation of matter and spirit; nature here becomes one with spirit, its concrete articulation, its spiritual body..$^{85}$

Solov'ev, 'Lektsii po istorii filosofii,' p. 79.

See the first chapter for a more detailed exposition of Soloviev's thought on matter and its derivation.

4 We find very little by way of a direct characterization of the physical aspect of the Resurrection body in Soloviev's thought. It should be stressed, however, that his ideal is directed not toward physicality per se, but its relationship with the spirit. Solov'ev, Dukhovnye osnovy, p. 97. 
The layering of agency involved in Soloviev's concept of theanthropy makes itself felt here once again. It is not only God who acts within nature but also nature which, in its search for transcendence, operates within God. And if the natural reaches the furthest point of its development in the human, then both aspects find their fulfilment in the God-man. The material world is not flung aside in Christ but risen up to new life, transfigured and glorified into the fullness of divine-human being. 'Jesus Christ, risen in the flesh,' writes Soloviev, 'showed that corporeal being is not excluded from the theanthropic union and that external and sensible materiality can and should become the actual weapon and visible reflection of divine power.' 86 In the risen body of Christ, material form is itself initiated into the historical movement of God's salvific plan for creation. If, before the Christ-event, the natural world had played a primarily static role, providing the material and backdrop for the action of God, it has now been put on an entirely new footing. Through the kenotic humanity of Christ in its act of putting itself 'in the proper relation of voluntary submission to, and agreement with, the divine principle, [humanity] again receives the meaning of a mediating, unifying principle between God and nature.' 87 In the Resurrection, through human agency, nature 'loses its material disconnectedness and weight, becoming the direct expression and weapon of the Divine spirit, the true spiritual body of the risen God-man.' 88 This resurrected matter, the body of Christ, now becomes the new subject of transformation; in the divinized humanity of Christ, the natural world is drawn into the logic of salvation history. In him it has shaken off its inertia, its selfcentredness, and opened up to the ideal future of the Kingdom of God.

Before Christianity the static foundation of life was human nature (the old Adam) and the divine the principle of change, movement, and progress. After Christianity, to the contrary, the divine itself, as already embodied,

86 SS, IV, p. 189.

87 S2, II, p. 160. Gorodetzky writes: 'the cosmic and historic process of penetration of all by the divine element reveals itself as self-denial.' N. Gorodetzky, The Humiliated Christ in Modern Russian Thought, New York, 1938, p. 132.

88 Solov'ev, Dukhovnye osnovy, pp. 96-97. Soloviev understands the Resurrection neither as solely a divine act, nor solely a human act, but the result of the perfect interaction between the two principles. It occurs 'through human agency' insofar as the kenotic movement is made on the part of the human being. 
becomes the static foundation and the element of life for humanity. The unknown quantity now is humanity in its answer to this divine, a humanity able to unite with the divine by its own resources [...] As in the pre-Christian historical era the foundation, or material, was human nature, the active and formative principle divine reason [...] and the result the God-man, i.e. God become human, so in the process of Christianity the foundation, or material, is the divine nature (the Word made flesh, or the body of Christ, Sophia), the active and formative principle human reason, and the result the man-god, i.e. humanity become God. ${ }^{89}$

Recalling Soloviev's definition of the divine-human task as the joint 'materialization of spirit,' and 'the spiritualization of matter' - the first the activity of the divine and the second that of humanity - we see here that these two aspects now receive an historical articulation. The activity of the divine on and in the world, from the earliest theophanies in nature through the emergence of the image of God within human consciousness, reach their end in the Incarnation of the God-man. In this climactic event, the human principle, which ideally represents the full interrelatedness of matter and spirit, is brought to completeness in the resurrected body of Christ, and this 'new flesh, the spiritual body of the risen Christ, from now on becomes the divine substance (substantsiia) of humanity. ${ }^{\prime} 90$ God has attained her goal; from now on the divine becomes the cornerstone of human reality, the unchangeable. The materialization of spirit has reached its conclusion. Human nature itself, which before was but the material for the historical realization of divine nature, now moves into a new phase. The post-incarnational period is

$S^{2}$, II, p. 169. Although stated in distinctively Solovievian terms, this passage concurs in all essential details with the doctrine of theosis, or deification, summed up in St Anathasius' words that God 'assumed humanity that we might become God.' Athanasius, On the Incarnation, Crestwood, NY, 1998, p. 93. In his reaction to Konstantin Leontiev's article 'Nashi novye khristiane. F. M. Dostoevskii i gr. Lev Tolstoi,' first published in the journal Rus' in 1883 ('Zametka v zashchitu Dostoevskogo ot obvineneniia v «novom» khristianstve') Soloviev quotes Athanasius' formulation, commenting that 'this belief is not heretical, but truly Christian, Orthodox and Russian (otecheskaia).' FI, p. 263. The opposition between the God-man and the manGod, understood in different terms, has a central place in the novels of Dostoevsky.

90 RNB, f. 171, op. 22, d. 5. 'Zhiznennyi smysl khristianstva,' p. 10 of 13. See also Soloviev's words in La Russie et l'église universelle: 'before Jesus Christ, humanity, deprived of an actual centre, was only an organism in potentiality; in reality only separate organs, tribes, towns and nations held sway.' SS, XI, p. 313. 
to be characterized by the spiritualization of matter, in which collective humanity transitions from a position of static materiality-the impenetrability of material form - to a dynamic and changing state whose condition and foundation becomes the newly constellated body of Christ, itself dynamically conceived and orientated.

An answer to the question as to how exactly the body of Christ represents this newly acquired dynamism is again to be sought in Soloviev's thought on the nature of material being. 'In the mechanical order,' he writes, 'the creature is not penetrable; in true being, however, it is open and penetrable. ${ }^{\prime} 1$ The character of material being is such that 'each [material object] becomes impenetrable and excludes the other.'92 In this is the condition for the inertia of the material world; the exclusionary principle rooted in nature cannot grow into newness but only subsist in its isolation and self-centredness. The spiritualized body of the God-man is a new revelation in the natural order since it no longer obeys the laws of the mechanism, whose ineluctability finds its ultimate confirmation in the law of death and decay, but represents 'the first decisive victory over death'; the 'new flesh' of Christ, Soloviev writes, is a 'weapon' used for the direct expression of the spirit. ${ }^{93}$ This instrumentalization of the corporeal body realized in Christ, its obedience to the spirit given at the core of his inner life, contrasts sharply with the law of material nature that the philosopher sees persisting in carnal reality.

Flesh is being that is not in control of itself, being that is wholly directed outwards [...] It is being that dissolves in externality and ends with actual decomposition. In contrast, spirit is being that is governed by inner determinations, being that has entered into itself and possessed itself, that acts outwardly with its own power, not losing itself or disintegrating in the flesh. ${ }^{94}$

The material aspect of human life, argues Soloviev, is disordered and disunited. Far from our bodies being an expression of the inner life of the spirit, which by nature is eternal, they exhaust themselves in externality,' literally and physically separating us from our neighbours

91 Solov'ev, 'Lektsii po istorii filosofii,' p. 78.

92 Ibid., p. 77.

93 SS, IV, p. 503.

$94 \quad \mathrm{~S}^{2}, \mathrm{I}, \mathrm{pp} .142-43$. 
and environment so that ultimately 'we are able to rid ourselves neither of corporeal death, nor of spiritual death. ${ }^{95}$ But in the ideal scheme of things, our bodies, Soloviev writes, should be the 'ultimate limit of the divine-human process as the pre-appointed dwelling-place of the Holy Spirit,' ${ }^{\prime 6}$ not separating us from every other physical thing but enjoying communion in oneness with them. In the risen body of the God-man, a new kind of flesh, a new kind of matter - penetrable and dynamic - first gains a foothold in reality. The goal, however, is that the spirit of God be manifest in all, that all may be brought into the fullness of salvation in the risen Christ. 'Collective resurrection,' Soloviev writes, 'is the creation of the perfect form for everything that exists, the extreme expression and realization of the meaning and goodness of the universe and therefore the end and goal of history. ${ }^{97}$ The creation that he speaks of here is synonymous with the task of the spiritualization of matter, the bringing of the material world into absolute correlation with the spirit, which Soloviev calls upon humanity to fulfil. In the God-man Christ, this act was realized at the focus of the universe; humanity must expand this salvation to the periphery of being, by 'relating to all in His Spirit and, through this, [...] making it possible for His Spirit to become incarnate in all. ${ }^{98}$ But this new activity is only possible insofar as God has acted first in Christ. Before Christ, the human being could act within and on the world only within the limits of its material being, linking the disparate elements of being within consciousness but powerless to unite them in reality. In the resurrection of Christ, however, 'God discovers the actual power of Her infinitude and humanity expands its actuality to the infinite fullness of God.'99 Humanity is henceforth able to relate the elements of the world not only in the ideal and interior space of reason but in the living spirit of 'existent reason.' By locating itself within Christ in the inner life of the now incarnate Word, humanity becomes one with him in his risen life and is conformed to his spiritual body. In this process, the interior

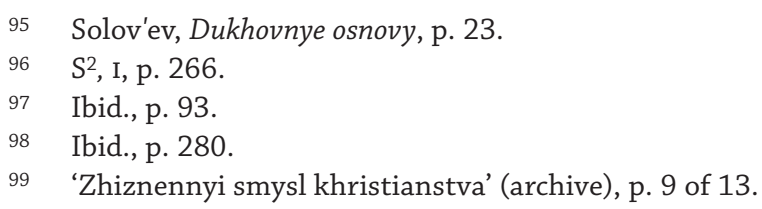


life of the Kingdom, which had remained self-enclosed in human consciousness until the Resurrection, transitions into externality in the flesh, not to disappear and dissipate, but to transfigure and dwell therein. But the limit of our human bodies does not represent the final object of spiritualization. For Soloviev the spirit of Christ, or 'the grace of God' as he calls it here, ${ }^{100}$ must become incarnate in all.

If we become channels of the grace of God, then we should spread its action onto both our animal nature and the whole of our world, for one cannot place limits to divine-human power. As the incarnate God saves humanity, so humanity in union with God must save the whole of nature; for as humanity in the form of the Church is the living body of Christ, so the entire natural world must become the living body of a risen humanity. The whole creation must be redeemed and drawn into the freedom of the glory of the sons of God. ${ }^{101}$

Like all the key moments in Soloviev's philosophy of history, it is important not to misinterpret the 'transition' which occurs as a result of the Christ-event as the beginning of an utterly new process, or an absolute end to the previous development. The growth of the Kingdom inside humaniyty that had culminated in the Incarnation is not arrested but merely deprived of its finitude as it is drawn into the fullness of the infinite in the new, dynamic body of Christ. What Soloviev had referred to as humanity's task of 'gathering the universe in the idea,' its theoretical task, is not superseded by the practical task, newly potentialized in the Resurrection, of gathering the universe in reality. The feat of Christ was, in Soloviev's view, to reduce the limitedness of his humanity to such an absolute correlation with the spirit that his inner life no longer met with the confines of materiality but penetrated this matter with a life that was stronger than its death. Human nature was thereby released-or redeemed, in soteriological terms - to transcend the interiority of its ideal, the Kingdom of God. This inner life no longer stands against

100 'The action of the grace of God has always existed in the world. But from the time of the incarnation of Christ it entered into a visible and sensible form. In the Christian church the divine has not only an inner dimension, the imperceptible action of the spirit, but also some kind of actualized form or corporeality.' Solov'ev, Dukhovnye osnovy, p. 108.

101 Ibid., p. 66. 
material life, for the latter has been brought within the sphere of the former. In conforming the world to God interiorly, therefore, a humanity divinized in Christ at one and the same time conforms the world to God exteriorly. The theoretical and the practical have become one, and reason itself becomes not 'thought as perceptive but thought as creative.'102 Fundamental to both sides of this activity, however, theory and practice, is the prior work of humanity in conforming itself to God.

Our practical task is to make our material environment penetrable to our will, or obedient to us; our theoretical task is to make the same environment transparent for our mind, clear and understandable to us. Both of these represent the same task. But for the fulfilment of the task, before all else, we must ourselves become radiant (svetlyi) and penetrable for all. ${ }^{103}$

To really share in the life of Christ, the body of humanity must enter into the inner dynamism of the body of the risen God-man, whose 'holy corporeality' (sviataia telesnost') is not a block to material form but a force for incorporation, making room for others within itself. The flesh of human beings should ultimately, in Soloviev's scheme, become like the flesh of Christ, penetrable and open to all. In this process, the disparate lives of human individuals, nations and cultures gradually join together as one body united in him whose dynamic materiality draws in the static, one-dimensional materiality of humanity, transfiguring and spiritualizing it. Soloviev describes this process of humanity's gradual incorporation into the body of Christ as 'theanthropy in a state of becoming (perfect)' (bogochelovechestvo sovershaiushcheesia), ${ }^{104}$ which he goes on to equate with the church.

102 PSS, III, p. 314.

103 Solov'ev, Dukhovnye osnovy, p. 74. If the foundation for the practical task is the body of Christ, the foundation for the theoretical is 'the mind of Christ' (um Khristov). See $S^{2}$, II, p. 308.

104 See Solov'ev, Dukhovnye osnovy, p. 108. This formulation marks a subtle reorientation of emphasis, although not of substance, from Soloviev's earlier philosophy in which, as we saw, he defines the subject of history, his so-called 'second absolute,' by the more professedly abstract phrase 'All-Unity in the state of becoming' (vseedinstvo stanoviashcheesia). This shift away from the condition, or goal, of life - i.e. unity toward the constituents of that unity, God and humanity, signals the philosopher's turn toward the covenantal philosophy and theology of history he accomplishes in History and Future of Theocracy. 
The determinative form of humanity as it is reborn into the Kingdom of God is the church. The church relates to natural humanity as this latter relates to the rest of earthly nature. It is in the natural human being that the ideal of earthly nature is realized; and it is in the church that the ideal of humanity is realized. ${ }^{105}$

It is not my intention here to offer a full account of Soloviev's multifaceted views on the nature and vocation of the Christian church. My goal is rather to explore his ecclesiology from the perspective of the historical task of humanity insofar as it is synonymous with the body of Christ. In History and Future of Theocracy, we find the following description of the threefold nature of the church, again couched in the biblical terminology to which Soloviev was increasingly turning during this middle period of his life:

Firstly, the church should exist on a real foundation; secondly, it should live and develop; thirdly, it should become perfect. From the perspective of its real existence, the church is a building created by Christ, the City of God, the New Jerusalem [... ] From the perspective of its life, the church is the living body of Christ. Finally, from the perspective of its perfection, the church is the immaculate bride of Christ. 106

Soloviev goes on to draw God's relation to the church in accordance with these, its three aspects, writing: 'God lives in the church as His temple; through the church as His body; and with the church as His wife or bride. ${ }^{107}$ If the first aspect of the church relates to the fact of its institution by Christ, its beginning point, and the third to the end point of its historical development, the second may be understood as the bridge between the two, that principle in which the post-incarnational period approaches the eschaton. That Soloviev connects the body of Christ precisely with the life of the church is perhaps unsurprising, but its importance should be underlined nevertheless. ${ }^{108}$ The body of

105 SS, IV, p. 605.

106 Ibid., p. 601.

107 Ibid., p. 602.

108 On the importance of 'life' (in Greek, zoe) in reference to Christ and the Church, particularly in the fourth Gospel, see 'The Concept of Life in the NT,' in Theological Dictionary of the New Testament, ed. G. Kittel and G. Friedrich, Grand Rapids MI, 1985, p. 294. On its development in Pauline thought, see R. Bultmann, Theology of the New Testament, 2 vols, London, 1965, I, p. 210. 
Christ is the life of the church in history, the principle of movement between its present reality and its future state of perfection. ${ }^{109} \mathrm{God}$ acts through his body, the church, and it is in this body that created humanity discovers the beginnings of the new life it is called to realize.

This new life is not only a construct of the mind but is dependent on the 'real-mystical link with Christ as the principle of theanthropy' embodied in the church. ${ }^{110}$ This link between Christ and humanity is sustained and supported in Soloviev's ecclesiology by many factors, ranging from apostolic succession to the profession of a shared creed, all of which have vital significance in his thought. But humanity can only actually participate in the theanthropic life through the communication of the holy sacraments as the beginnings of a new, spiritual corporeality and life of grace (Christ as life in us).'111 Its sacramental life, and in particular the Eucharist, is thus envisioned as the very lifeblood of the church, the guarantor of its continuing vitality and efficacy. The sacraments are understood here as the bearers not of tradition, nor of right belief, but of the Christ-event itself, and the newness that thereby became incarnate in history. As Soloviev writes, 'in them are given the actual beginnings of the spiritual-corporeal interaction of God with humanity.'112 They are the receipt of the given, the 'gift' of the body of Christ as already risen and glorified. The 'inner meaning and purpose [of the Eucharist] is the spiritualization of human sustenance (and, correspondingly, the whole corporeal structure of humanity) through its incorporation into the sphere of the spiritual corporeality of the God-man Christ. ${ }^{113}$ In a passage from the final part of La Russie et l'église universelle, Soloviev directs himself to those who officiate the gifts of God to the people - the priests of the church:

'Real ecclesial substance,' comments the liberation theologian Jon Sobrino in the same vein, 'is the realization of the true body of Christ in history.' J. Sobrino, 'Communion, Conflict and Ecclesial Solidarity,' in Mysterium Liberationis: Fundamental Concepts of Liberation Theology, ed. I. Ellacuria and J.Sobrino, Maryknoll NY, 1993, pp. 615-36 (p. 630).

$110 \quad S^{2}$, I, p. 159.

111 Ibid., p. 159.

112 Ibid., p. 123.

113 Ibid., p. 123. 
As Christ is one in His hypostasis, infinitely diverse insofar as He contains within Himself and reveals the ideal cosmos, and trinitarian insofar as He unites the divine essence with the rational soul of humanity and with material corporeality [...] so in the holy sacraments Christ is the principle of life, all life, not just spiritual but corporeal, not just individual but social. You, the offerers of the sacrifice, you are they who are appointed to sow the mystical but real grain of theanthropic life in humanity, you are the sowers in our nature of a divinized matter, a heavenly corporeality. The beginning of this task, the first source of a life that is more than natural in the earthly body of humanity should be an absolute fact that exceeds human reason, a mystery. But every mystery needs revealing, and the mystical elements which, in the grace of the sacraments, make their home in human nature should through your service enter, grow and become manifest in visible existence, in the social life of humanity, transforming it more and more into the living body of Christ. ${ }^{114}$

Particularly clear here is the emphasis on what Soloviev calls the 'Trinitarian' aspect of Christ, the conjoining in his one person of the divine, human, and material natures. The life of Christ is thus the allreconciling unity of a being that has outgrown itself to include the totality of life, both divine and material, individual and universal. Alongside this, however, the philosopher is at pains to emphasize, in a way that is often lacking in other areas of his work, the mystery both of the Christ-event and of the sacramental life of the church. The sacrament, the beginning of new life in creation given through Christ, is inaccessible to reason for it is precisely reason that is transcended, albeit by an initial act of the rational will, in the feat of the God-man. ${ }^{115}$ Humanity cannot work its way to salvation by its own means but must find its centre in the 'absolute fact' of the Christ-event as the condition for its own dwelling in God. The incorporation of humanity within the church as the body of Christ can thus only occur insofar as there has already occurred the prior act of God in Christ who, 'having transformed His material (mechanical) body into a spiritual (dynamic) one [...] gives it as food to humanity.'116 God makes herself available

114 SS, II, p. 342.

115 Here again, Paul's words may serve as an approximate expression for this fundamental paradox. As he writes in his letter to the Galatians, 'through the law I died to the law, so that I might live to God.' Gal 2:19.

116 Solov'ev, Dukhovnye osnovy, p. 99. 
to humanity in the sacrament as the possibility of a new life other than the natural life of death and decay.

In this way, Soloviev extends his kenotic understanding of Christ beyond the sacrifice of his own self on the cross and the consequent victory over death in the Resurrection to his enduring presence in the sacramental life of the church. This life is sustained through Christ's perpetual kenosis, understood here as the continuing openness and self-giving of his body to the historical life of the church. ${ }^{117}$ Communion with this life through the sacrament, however, is not merely a matter of receiving. According to Soloviev, to receive this food as gifted by God, to participate in the actual life of the church as the body of Christ, requires not so much a determined resolution of the will but its own kenotic movement, the transference of will into a state of pure passivity.

Before the sacrament, the human will completely renounces everything that belongs to it, remaining in perfect potentiality, or purity, and thus becoming able, as pure form, to receive a supra-human content. Through the sacraments, that unitary and holy essence which is the Church initself (Ding an sich, or the noumenon of the church, in philosophical terminology), unites or incorporates within itself the inner essence of the human and makes the life theanthropic. ${ }^{118}$

117 There has been much debate in both unreformed and reformed churches surrounding the Council of Trent's affirmation that the 'sacrifice of the mass' represents a repetition of the sacrifice of Christ on Calvary, only after a different, unbloody fashion. For a description of the proceedings at Trent, see J. F. McHugh, 'The sacrifice of the mass at the Council of Trent,' in Sacrifice and Redemption: Durham Essays in Theology, ed. S. W. Sykes, Cambridge, 2007, pp. 157-81. For an analysis of the theological questions involved in the notion of sacramental sacrifice from a Catholic perspective, see M. McGuckian, 'The Sacramental Sacrifice,' in The Holy Sacrifice Of The Mass: A Search For An Acceptable Notion Of Sacrifice, Mundelein, IL, 2005, pp. 107-33. The idea of an eternal kenosis should not be equated with an eternal suffering of God. Hans Urs von Balthasar has written much more persuasively of this kenotic economy than Soloviev, but their thinking on the subject is essentially the same. Balthasar writes of 'Godgiven Being [which] is both fullness and poverty at the same time: fullness as Being without limit, poverty modelled ultimately on God Himself because He knows no holding on to Himself, poverty in the act of Being which is given out, which as gift delivers itself without defence.' Graham Ward cites this statement to conclude that the 'kenotic economy is an economy of life through death, eternal resurrection through eternal crucifixion, an eternal giving of thanks through an eternal brokenness.' See G. Ward, 'Death, Discourse and Resurrection,' in L. Gardner, D. Moss, B. Quash and G. Ward (eds), Balthasar at the End of Modernity, 1999, pp. 15-68 (p. 52). $\mathrm{S}^{1}, \mathrm{I}, \mathrm{p} .513$. 
The Eucharist thus involves two distinct, though inseparable, elements: firstly, the kenotic offering of God's self in the body of her Son, and, secondly, the renunciation of self on the part of the individual communicator. In both, however, is the limited, individual humanity of each party overcome, not in a static and immobile glory, but in the 'theanthropic life' of Christ, the shared life of God and humanity. Soloviev's position on the Eucharistic sacrifice should not therefore be interpreted in terms of a repetition of the one sacrifice of Jesus Christ on the cross, as formulated by the Council of Trent, for his understanding of sacrifice is not restricted to a single event which is then carried through in a series of future re-enactments. It is not so much that he sees Christ's sacrifice as repeated in the sacrament but rather that sacrificiality - the law of self-giving - has itself become the life of the church with its centre in his risen body. The freedom which is opened up in the dynamic unity of the body of Christ, freedom from the finitude of human aspiration, is attained through the giving-away of self to the other. ${ }^{119}$ The 'supra-human' is assimilated not through a pushing-through to the other side of humanity but by its reduction to 'pure form,' a state of pure passivity and potentiality.

This law of self-giving, founded in the human feat of Jesus Christ and continued in the sacramental life of the church, in Soloviev's conception becomes the law not only of the workings of God and humanity but also of nature; the economy of the Son is seen as the sacrament of a broader economy that embraces both human and material worlds. The goal of this broader economy is to bring the realized salvation in Christ to its very outermost point, or 'circumference' as Soloviev calls it. As collective humanity grows into the body of Christ, entering more fully into the law of his sacramental self-giving and allowing room for

119 It is interesting in this connection to note the more general reflections of Jacques Derrida in his enquiry as to the essence of religion. 'However little may be known of religion in the singular, we do know that it is always a response and responsibility that is prescribed, not chosen freely in an act of pure and abstractly autonomous will. There is no doubt that it implies freedom, will and responsibility, but let us try to think this; will and freedom without autonomy. Whether it is a question of sacredness, sacrificiality or of faith, the other makes the law, the law is other: to give ourselves back, and up, to the other. To every other and the utterly other.' J. Derrida, 'Faith and Knowledge: The Two Sources of "Religion" at the Limits of Reason Alone,' in Acts of Religion, New York, 2002, pp. 40-101 (p. 71). 
the other, in so doing it makes room and incorporates within itself the material world around it. Just as the penetrable materiality of the body of Christ allows all that is human to commune within it, becoming the vessel for collective humanity, so the actualized-in-Christ penetrability of this new human organism opens up to incorporate within itself the entire natural world. The human form, in the life of the church as the body of Christ, becomes the potential receptacle for the material multiplicity of the world: not just the gatherer of the universe in the idea but, in and through Christ, the gatherer of the universe in reality.

\section{DEATH AND FLESH}

One of the notable things about Soloviev's Christology of the early and middle periods is the lack of attention he pays to the concrete conditions of the death of Christ, to the despair and abandonment of the cross. There is no doubt that it is there, in the background, but the philosopher's mind always seemed to rush forward in anticipation to the moment of resolution, the glory of the Resurrection that lay beyond the cold tomb. Mochul'skii writes perceptively in this regard that 'redemption for Soloviev meant victory over the three temptations [...] The struggle at Gethsemane and Golgotha, the Saviour's actual acceptance and living through of the sins of the whole world, his death and victory over death [...] go almost unmentioned' until later in his life when his 'evolutionism is replaced by apocalyptic thinking. ${ }^{120}$ Yet a condemnation of the phenomenon of death, rooted in one of the three fundamental feelings we earlier associated with the philosopher - an abhorrence for decay - and the conviction that, as Paul writes, in Christ death has 'lost its sting' ${ }^{121}$ are crucial to an understanding of his

120 Mochul'skii, Zhizn' i uchenie, p. 102-03. Compare also Levitskii's comment that 'the image of the imperishable beauty of Sophia outweighed in [Soloviev] the image of the suffering Christ; the mystery of the resurrection sometimes pushed the mystery of Golgotha into the background.' S. Levitskii, 'Vl. Solov'ev i Dostoevskii,' Novyi zhurnal, 1955, 41, pp. 197-209 (p. 206). In his book on the role of evil in Soloviev's thought, Jan Krasicki uses such biographical details to present a profoundly exaggerated picture of the change that occurs in Soloviev's late period. See Krasitskii, Bog, chelovek i zlo.

See 1 Corinthians 15.55-56. 
position throughout. 'Without the power of good,' he writes, 'without the possibility of its final victory over everything up to and including the "final enemy" - death - life would be fruitless.'122 The 'life' of Christ that Soloviev saw operating in the sacraments of the church as his body was a life that is not, nor can be, negated by death. Understood sacramentally, as the continuation of the work of Christ, the task of the spiritualization of matter is necessarily the transition of all that is natural into the realm of immortality.

By the free and conscious activity of a resurrected-in-Christ humanity, the death-dealing tree of its old nature, whose root is sin, whose growth is illness and whose fruit is death, should be transformed into the eternal tree of new life which is rooted in love and brotherhood, grows by the cross of spiritual battle and reaps the fruit of universal resurrection. ${ }^{123}$

Despite this emphasis on the conscious eradication of death, however, Masing-Delic's conclusion that Soloviev's system amounts to a kind of 'immortalization programme,' needs to be significantly expanded if it is to be accepted. In a passage from one of his late Sunday Letters (1897-98), Soloviev writes:

We die because our spiritual power, interiorly bound by sins and passions, proves insufficient to claim, incorporate and transform into itself our entire external, corporeal being; it falls away and our natural immortality (until the final resurrection, to which we can attain only through Christ) is only half-realized, only our inner dimension is eternal, only the fleshless spirit. Yet Christ was risen as one whole (vsetselo). ${ }^{124}$

In Soloviev's thought, death is not the default condition of human nature but a sort of intruder. The natural immortality of humanity is not in need of explanation, for it is bound up with the fact of being human. The enigma for the mind is rather the very fact that we die, that our eternal spirits are overtaken by what Soloviev considered the base laws

123 Solov'ev, 'Zhiznennyi smysl khristianstva,' p. 63-64.

124 SS, x, p. 36 (my emphases). 
of physical existence. ${ }^{125}$ Humanity is not, in his view, made immortal, nor does it make itself immortal, but 'rediscovers' its immortality as rooted in the image of the eternal God. ${ }^{126}$

But what exactly did immortality mean for Soloviev? Following Paul and faithful to his own thinking, the philosopher could not rest on the immortality of the soul without the body: Christ was risen as one whole, body and soul. Yet there is a key difference between the approaches of Paul and Soloviev on the question of what is involved in the spiritualization of the body, and its immortalization in a new form. The two key concepts in Pauline anthropology are $\sigma \dot{\rho} \rho \xi$ (sarx) and $\sigma \dot{\omega} \mu \alpha$ (soma), which in the majority of cases translate into English as 'flesh' and 'body' respectively. With the word 'flesh' ( $\sigma \alpha \dot{\alpha} \xi)$ he designates 'the whole person, considered from the point of view of his external, physical existence' but, crucially for the present consideration, 'man in contrast with God,' the state of humanity's being in the natural world that separates it from God and every other thing around him. The flesh for Paul is thus the principle of individuation and to live 'according to the flesh' is to live in opposition to God and to be controlled by the powers of this world - sin and death. ${ }^{127}$ While the 'body' ( $\left.\sigma \dot{\omega} \mu \alpha\right)$ also means the external presence of the whole person and 'repeats all the emphases of $\sigma a \dot{\rho} \rho \xi$ before it diverges from it,' it is also for Paul 'the carrier of the

125 Far from softening in later life, Soloviev's viscerally negative assessment of the phenomenon of death only became more pronounced. In Three Conversations, he describes it through the mouth of his protagonist as 'the extreme evil.' In Justification of the Good, he writes of the 'very process of death as physical lawlessness, as the victory of the blind and soulless force of poisonous matter over a living, organized body in which a rational spirit had become incarnate.' S1, II, p. 727; I, p. 324.

126 There is a great deal of literature from the early Christian period on the question of natural immortality, which was often seen as the preserve of Greek philosophy rather than the Hebrew Bible. For a fine introduction to the problem, see R. Swinburne, 'Soul, nature and immortality of the,' Routledge Encyclopaedia of Philosophy (1998) <http:// www.rep.routledge.com/article/K096SECT2> [accessed 10 June 2008]. While Soloviev was heavily influenced by Plato and Leibniz, both of whom regarded the soul as innately immortal, he seeks to correlate their views with Christian thought, positing the source of immortality both inside the soul and outside it, at its divine source.

127 On an anthropological plane, Pauline 'flesh' is thus equivalent to the character of Soloviev's materia prima, or Satan, on the metaphysical plane. My argument here and in what follows is based on Robinson's insightful treatment of the Pauline concepts in The Body, pp. 17-33. 
resurrection.' Thus, while ' $\sigma a \dot{\rho} \rho \xi$ stands for man, in the solidarity of creation, in his distance from God, $\sigma \omega \dot{\mu} \mu \alpha$ stands for man, in the solidarity of creation, as made for God.' ${ }^{128}$ In this way, the two terms carry much of the same meaning, and have to do with a human being's external or physical life not considered in itself but in its relation to God. When Paul speaks of 'putting off the body of flesh'129 he is not therefore pointing to the stripping away of inherently evil matter but to a correction in the human's relationship to God. Flesh, or matter, is for Paul not evil in itself, as it was for the vast majority of Gnostic worldviews; it is the relationship of the human being to God through his body that is liable to be corrupted through sin, not the body in and of itself. 130

Soloviev's position does not differ from Paul's in substance. For the Russian philosopher, the body is both the potential receptacle for the fullness of theanthropic being, when united with God, and the principle of self-centred isolation when blocked off to divine influence. The elements of $\sigma \dot{\alpha} \rho \xi$ and $\sigma \dot{\omega} \mu \alpha$ are both present as strongly as they are in Paul. But we find a subtle change of emphasis from the Pauline conception in Soloviev's treatment of the body of Christ, the process it inaugurates, and the transformation of the human personality involved. If the body itself as corporeal form is Paul's central idiom, for Soloviev it is rather the materiality of the body, that of which it consists - content, not form. It is not in our bodies that Soloviev posits the historical locus of transformation but our flesh. 'We know,' he writes in Spiritual Foundations, 'that our flesh (plot') is the earth from which and on which should grow the tree of eternal life, that earth which God wishes to flourish and be fruitful. ${ }^{131}$ Such a statement

128 Ibid., pp. 26-27, 31.

129 Colossians 2.11.

130 This understanding of Pauline 'flesh' had been evident before Soloviev in Russian biblical exegesis. See, for example, F. A. Golubinskii and D. G. Levitskii, Premudrost' i blagost' Bozhiia v sud'bakh mira i cheloveka (o konechnykh prichinakh), St Petersburg, 1907 (first edition: 1853). '[By flesh] the Apostle understands not only the sensual side of human nature, but the whole person with its sensuality, its mind, the entirety of its sensual and spiritual urges, dispositions, contemplations and actions in their disobedience to the law of the spirit of God. Flesh means the same as the person of the soul (dushevnyi chelovek), i.e. sinful, opposed by the Apostle to the spiritual person, sanctified by the grace of the Spirit (p. 116).'

131 Solov'ev, Dukhovnye osnovy, p. 40. 
would have been impossible for Paul since for him flesh is precisely that part of human existence which must be 'stripped away' to incorporate humanity within God through the body of Christ. Soloviev's use of the word 'flesh' here is a conscious decision to diverge from biblical usage. ${ }^{132}$ What Soloviev is suggesting is that it is the very exteriority of the human person to God - the 'body of sin' or the flesh ( $\sigma \alpha \dot{\rho} \rho)$ that for Paul must be stripped away - that is to become the carrier of the new life available to all through Christ. The 'matter' of the world whose primary characteristic is to exclude all others in its egoistic erecting of barriers for the other (as outlined in Chapter 1 ) is itself to become the foundation for the new movement in the body of Christ. The very principle of evil and sin - the energy of individuation and selfassertion - is incorporated within this body such that its fundamental character, though unchanged, serves a purpose other than separation and isolation. ${ }^{133}$ In this sense, we find the same puzzling 'coincidence of sinlessness and sinfulness' in Soloviev's handling of the person of Christ that a recent commentator has read into the theology of Karl Barth. ${ }^{134}$ 1883 saw the publication, in the journal Pravoslavnoe obozrenie, of Soloviev's 'The Lived Meaning of Christianity,' which he had written

Soloviev was very clear on the meaning of the word 'flesh' in the biblical thought. In Justification if the Good, writes: 'Not in itself, but only in its deficient relation to spirit, is the material nature of humanity that which the Bible calls flesh.' S1, I, p. 140.

Note the following passage from Lectures on Theanthropy: 'the essence of good is given through the activity of the divine but the energy for its manifestation in humanity can only be the transformation of the subdued power of a self-assertive personal will, which has transitioned into a potential state. [The saint] has conquered the power of evil by subordinating it to its higher principle and it has become the foundation and carrier of good' (my emphases). S², II, pp. 150-51. It should be said that Paul can, in places, be seen as following an argument not dissimilar to that of Soloviev. See, especially, the paradoxical statement of 2 Cor. 5.21: 'For our sake he made him to be sin who knew no sin, so that in him we might become the righteousness of God.'

In his engaging discussion of the theme, Paul Jones puts particular emphasis on the receptivity of Christ's flesh in Barth's handling: 'As the nails are forced into his receptive flesh, in the moment at which he 'welcomes' sin into his being, Christ has actually become the sin that God rejects (thus 2 Cor. 5:21) [...] This entails more than Christ 'taking the negativities of existence into unbroken unity with God' [as in Tillich]. It entails Christ being the person in whom the horror of sinful hostility against God is halted, cancelled and rendered quite impossible.' P. D. Jones, 'Barth and Anselm: God, Christ and the Atonement,' International Journal of Systematic Theology, 12, 2010, 3, pp. 257-82 (p. 278). 
the previous year. ${ }^{135}$ The article is a philosophical commentary on the Logos theology of the fourth Gospel, an interest in which Soloviev nurtured his entire life. 'The truth of Christianity,' Soloviev summed up his argument toward the end of the article, 'consists in the spiritualization and divinization of the flesh.' ${ }^{136}$ While the substance of the body of Christ is entirely irrelevant for Paul, for Soloviev, to the contrary, it is the entire point. ${ }^{137}$ The risen body of the God-man is significant not so much because it is a body, that is, a corporeal and corporate form for collective humanity, but insofar as it consists of a new spiritualized matter, a divinized flesh. Christ's mystical role in the church is understood by Soloviev in terms of the change which the Christ-event has wrought in matter itself. "The word was made flesh and this new spiritualized and divinized flesh remains the divine substance of the Church.' ${ }^{138}$ It is the very materiality of the body of Christ that is foregrounded, a new matter which does not obey the laws of the mechanism but 'opens up' to the other, including it within itself: a matter in which the kenotic law of self-giving has become the guiding principle of its being. Such a materiality is hard to conceive, indeed perhaps impossible, for no matter how hard Soloviev tries to express it, there remains an unknown and unspoken aspect to his thought on the body of Christ such that it never quite gels with the contradictory formulations and reformulations he uses to define it. Important to remember, though, is that, as with all 'new' developments in Soloviev's

135 A further, drafted version of this article exists in the archives, with several fascinating passages that were left out of the final edit (see, for example, Chapter II, note 88). See Rossiisskaia natsional'naia biblioteka (RNB), f. 171, op. 22, d. 5. 'Zhiznennyi smysl khristianstva.' The article was reworked into the first chapter of the second part of Spiritual Foundations of Life (1882-84), with the omission of several more passages and the insertion of additional material. A seeming misprint in the original publication (1872 instead of 1882) has led several authors to claim this piece as Soloviev's earliest work, a claim that has been largely discounted on the weight of the evidence. For more details, see Kozyrev, Solov'ev i gnostiki, p. 237. Solov'ev, 'Zhiznennyi smysl khristianstva,' p. 60.

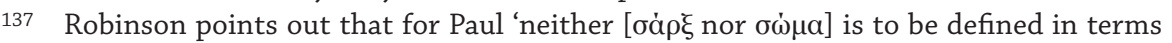
of the stuff of which it is composed [...] [ $\sigma \dot{\omega} \mu \alpha$ ] fulfils its essence by being utterly subject to Spirit, not by being either material or immaterial [...] Creation transfigured at the Parousia may or may not be physical-its substance is quite irrelevant.' Robinson, The Body, p. 32.

Solov'ev, Dukhovnye osnovy, p. 124. 
philosophy of history, the new matter of the body of Christ does not negate the matter of the world but realizes those initial strivings for selftranscendence that had resulted in the emergence of the human being and, eventually, in the Incarnation. The historical process in Soloviev is to be thought of as a synchronic whole: its first stage moves from the circumference of the circle to its centre - the Christ-event - and the second from this centre toward a repossession of the circumference. In contrast with the first stage of history, in which humanity is necessarily defined by the limits of its natural being, the divinized matter of the body of Christ has now been gifted to humanity so that, in the body of Christ, whose seeds are present in the sacramental life of the church, humanity may extend this spiritualized matter to the entire created order. It is for this reason that Soloviev treats the terms 'spiritualization' (odukhotvorenie) and 'humanization' (ochelovechenie) as synonymous. ${ }^{139}$ The spiritualization of matter cannot take place without its humanization, for in the theanthropic life of the God-man humanity has been brought within the realm of the spirit. The divine and the human are one in the spiritualized corporeality of Christ. To speak about 'spiritualization' is thus to speak of 'humanization,' both of which are perfected in the God-man. In the final stage of history, the salvation that came through Christ is to be channelled, as it was in his person, through humanity, so that the material world becomes the substance and expression of the body of collective humanity.

139 'The fate of humanity, our rising above our animal nature,' writes Soloviev in his essay on the poetry of Aleksei Tolstoi, 'mainly depends on the humanization and spiritualization of these fundamental facts of life, on their rebirth from the blind instincts of nature into the conscious principles of worthy existence.' FI, pp. 496-97. 